\title{
NOTES ON A COLLECTION OF FISHES FROM THE ISLAND OF FORMOSA.
}

\author{
By David Starr Jordan, \\ President of Leland Stanford Junior University, \\ and \\ Barton Warren Evermann, \\ Ichthyologist of the United States Fish Commission.
}

The island of Formosa is now part of the Japanese Empire. Beyond the general fact that its fauna must be similar to that of the neighboring coasts of China and the Philippines, scarcely anything is known of its fishes. In the present paper is given the record of two collections made under Japanese auspices. The first was obtained by Mr. Tsunasuke Tada, teacher in the Middle School at Osaka, for the Imperial University of Tokyo. The second was obtained by Japanese naval officers and others for a fisheries exhibit in Tokyo, and has been deposited in the Imperial Fisheries Institute or School of Fisheries of Tokyo. The latter collection was placed in our hands by Dr. Shinnosuke Matsubara, director of the Fisheries Institute. These specimens are without other locality than "Taiwan," and are apparently a series of the common market fishes of the port of Keerun (Keelung), the chief port of Formosa. This collection contains but few duplicates. The collection of Mr. Tada was made in six localities: Keerun, Taihoku, Giran, Toii, Suwata (Suwo Bay), Kotosho, and Hokoto. Taihoku is the capital of Formosa on the Tan Sin (fresh water) river. Keerun (Keelung) is its seaport at the north end of the island. Giran is a neighboring seaport to the eastward of Keerun. Toii and Suwata are near Giran. Hokoto, or Pescadores, is a large group of islands to the westward of Formosa; Kotosho a smaller group to the southeastward. Giran is about 50 miles to the westward of Ishigaki, in the Riukiu group. This collection is made up chiefly of small fishes, but among them are numerous duplicates, of which specimens have been placed in the United States National Museum and in the Museum of Stanford University. 
The authors are indebted to Mr. Edmund Heller for a preliminary identification of part of the collection, a piece of work which other duties have prevented him from completing. Important aid has also been given by Mr. Michitaro Sindo.

In the following list the specimens received from the Fisheries Institute without other locality than Taiwan (Formosa) and returned to that institution are marked F. I. The specimens have mostly Japanese collectors' numbers, $1 \mathrm{x}, 2 \mathrm{x}$, etc.; those not so provided were given numbers by us. These numbers, remaining attached to the specimens for purposes of identification, may serve as a convenience to future students in Japan. The following genera and species seem to be new to science:

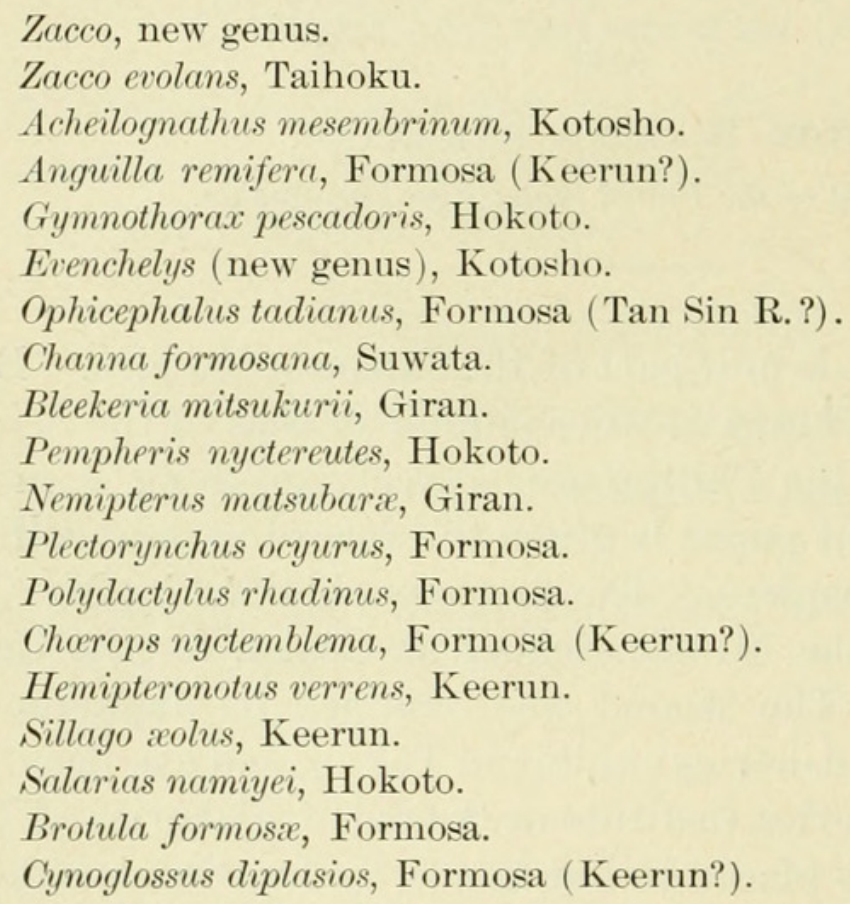

Family HEMISCYLLIID A.

\section{CHILOSCYLLIUM INDICUM (Gmelin).}

We refer our specimen to Chiloscyllium indicum, although the dorsal fins are somewhat farther apart than is shown in Dr. Day's figures of that species, separated by an interspace equal to the distance from the snout to base of pectorals. The snout is a little shorter than in $C$. indicum, 2.1 in head.

Description of specimen No. 1638, F. I., Formosa: Length, $685 \mathrm{~mm}$; head and body (snout to anus) 3 in length; head 2.5 in head and body; snout 5 in head and body; snout to mouth 4.5 in head and body; pectoral 3 in head and body; ventrals 4 in head and body; height first dorsal 1.4 times the base; interspace of dorsals 2.75 base of first dorsal.

Head flat above, the interorbital portion slightly concave; back with a low median ridge extending from above pectorals nearly to first dorsal, another between the dorsals, and one posterior to second dorsal. 
Pectoral wide, rounded, beginning between second and third gillslits; first dorsal slightly higher than second, truncated and beginning slightly posterior to posterior base of ventrals, separated from second dorsal by an interspace equal to length of pectoral; second dorsal similar in shape and size to first dorsal, situated considerably in advance of anal, from which it is separated by an interspace nearly equal to base of anal; anal low, rounded anteriorly and separated by a deep notch from the caudal; caudal long and low, length more than onehalf head and body, truncated posteriorly and deeply notched below near the tip. Mouth wide, width equal distance of spiracle from first gill-slit; distance from tip of snout slightly less than one-half snout; inferior labial fold continuous; angle of mouth somewhat nearer eye

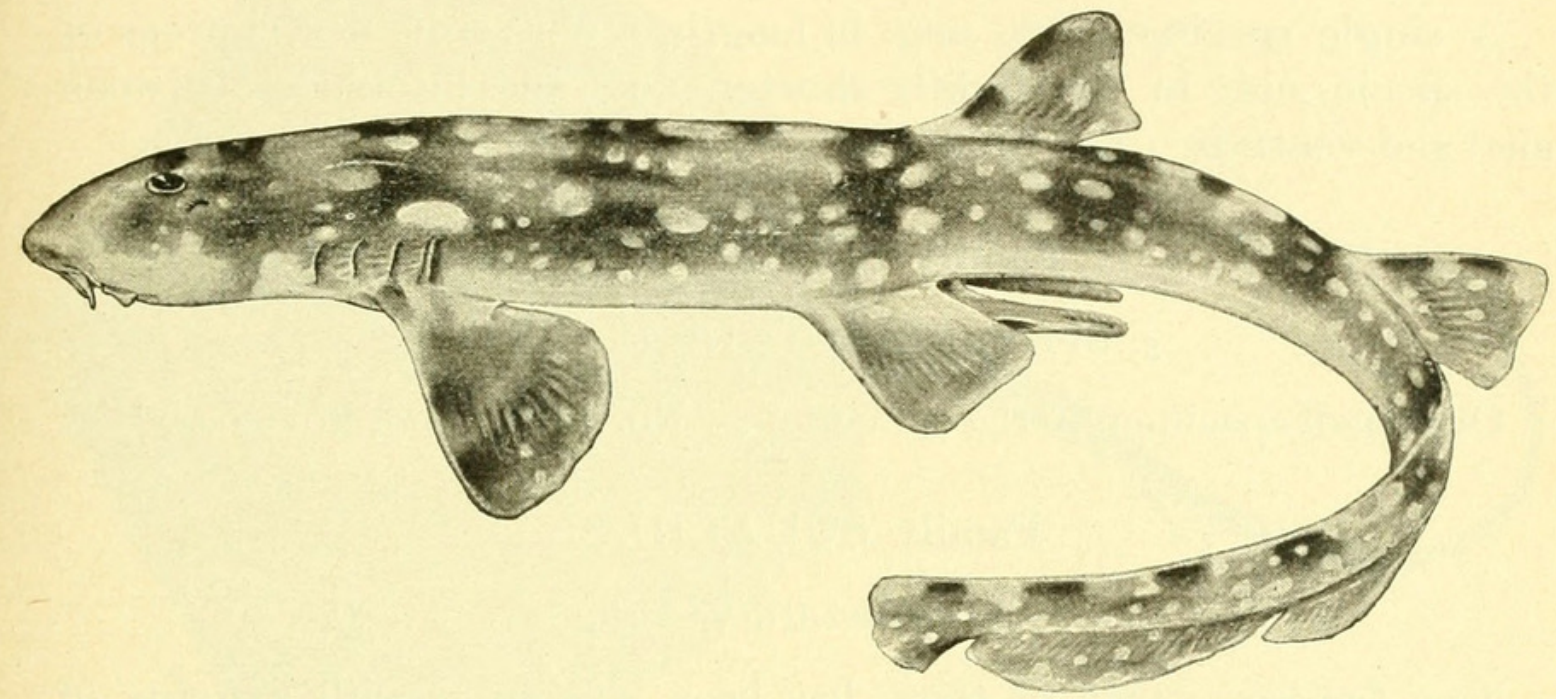

Fig. 1.-ChiLOSCYLhIUM INDICUM.

than tip of snout; nasal tentacles slender, tapering, length equal to diameter of eye; teeth triangular, with a pair of small lateral cusps at the base of medium size.

Coloration, above grayish, marked with about 9 broad transverse bands of brownish inclosing light spots; pectorals, dorsals and caudal spotted like the back; below light grayish or yellowish-gray, unspotted.

Only one specimen in the collection which has been returned to the Fisheries Institute.

\section{Measurements.}

Length, $685 \mathrm{~mm}$.

Snout to anus, $236 \mathrm{~mm}$.

Head, 41 (hundredths of length to anus).

Snout, 19.

Interorbital, 12.

Snout to mouth, 9.

Pectoral, length, 35.

Ventral, length, 26.
First dorsal, height, 27.

First dorsal, base, 20.

Second dorsal, height, 26.

Interspace of dorsals, 36 .

Caudal, length, 55 .

Base of anal, 25.

Second dorsal to anal, 23.

Dr. Günther records Chiloscyllium indicum from Formosa ${ }^{1}$ and Nystrom records it from Nagasaki. 


\section{Family GALEORHINID E.}

2. TRIAKIS SCYLLIUM Müller and Henle.

Three small specimens in the collection, all unspotted: No. 6169, Formosa, F. I., $6173(74 \mathrm{x})$, Formosa, F. I., 6444 (72x), Formosa, F. I. A larger one, No. 12250, Formosa, F. I., is spotted and banded as in Japanese specimens.

\section{GALEORHINUS JAPONICUS (Müller and Henle).}

One rather small specimen, $570 \mathrm{~mm}$. in length, No. 6168, Formosa, F. I.

\section{SCOLIODON WALBEEHMI (Bleeker).}

A single specimen, $525 \mathrm{~mm}$. in length, differs from descriptions of this species only in the slightly shorter snout and interspace between anal and ventrals. No. 6166 , Formosa, F. I.

\section{Family SPHYRNIDA.}

5. SPHYRNA ZYGÆNA (Linnæus).

One small specimen in the collection. No. $73 \mathrm{x}=6165$, Formosa, F. I.

\section{Family SQUALIDA.}

\section{SQUALUS, species.}

Two fœtuses. One of these has been compared with a fœtus of Squalus mitsukurii, from Misaki. The Formosa specimen has the dorsal spines considerably lower and the snout shorter. It may belong to some different species. Dorsals and pectoral largely black, with white edgings in both. No. 6169 , Formosa, F. I.

\section{Family RHINOBATID A.}

\section{RHINOBATUS SCHLEGELI Müller and Henle.}

Our specimen, which is $490 \mathrm{~mm}$. in length, is without tubercles on the median line of back. No. 6170 , Formosa, F. I. $=70 \times x$.

\section{Family DASYATIDA.}

\section{DASYATIS AKAJEI (Schlegel).}

Description of specimen No. $6445=77 x$, Formosa, F. I. Length of disc, $210 \mathrm{~mm}$; width $1 \frac{1}{8}$ length; snout 4 times in length of dise; interorbital width twice snout; tail 2 times length of disc; disc somewhat broader than long and rounded at the pectoral angles; snout slightly produced beyond the oblique anterior edges of the dise; interorbital space with a large triangular depressed area; snout with a 
shallow median groove; eyes smaller than the large spiracles; ridge of back with a series of blunt spines, the interscapular one largest; a short series of three or four spines on the scapular region running parallel to the median series; dental laminæ slightly undulated; floor of mouth with three tentacles.

Cutaneous fold along inferior surface of tail distinet, height about one-half pupil, beginning below caudal spine and extending to middle of tail; a much shorter and somewhat lower fold on superior surface of tail situated a considerable distance behind the spine; base of tail armed above with a median series of five stout spines situated some

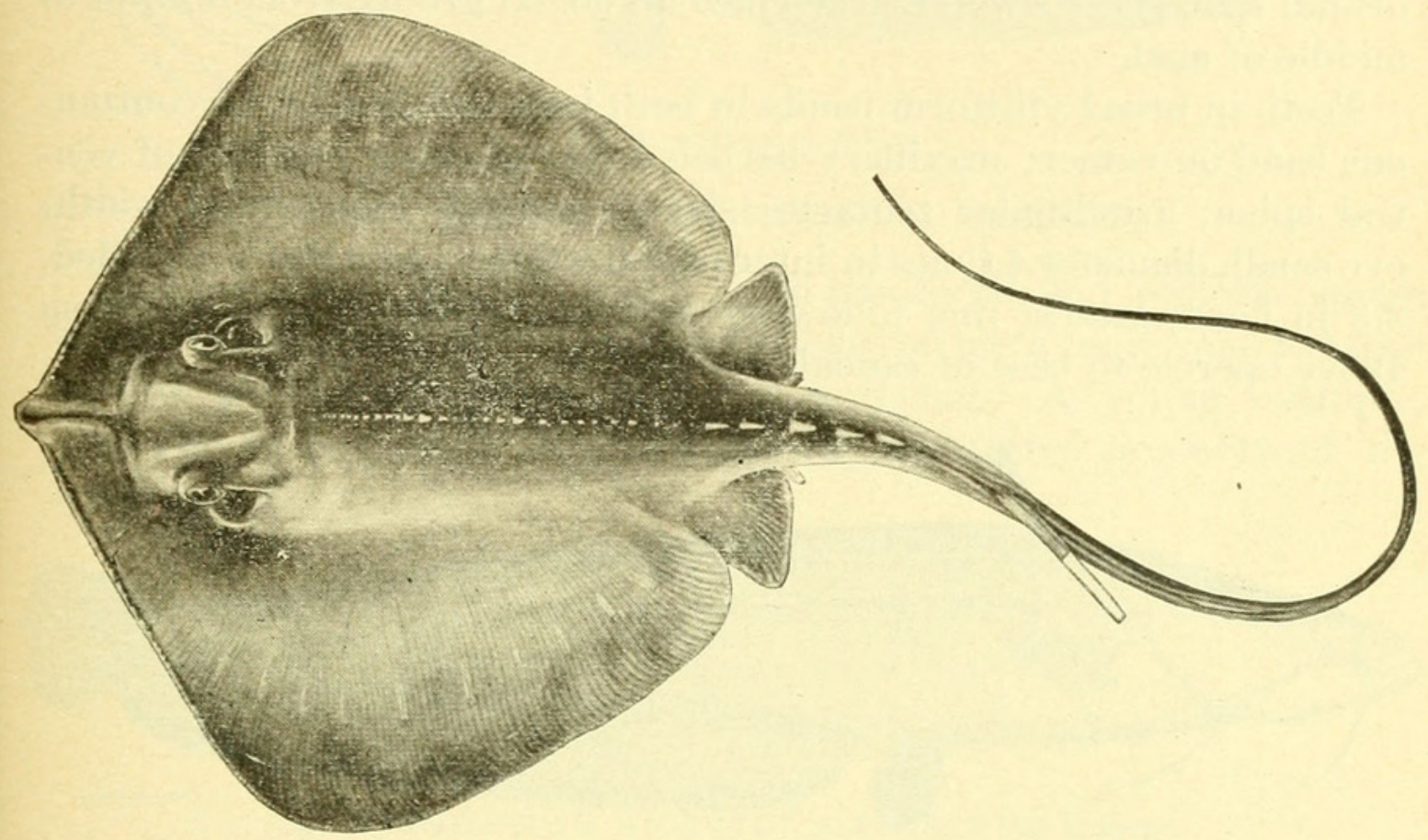

Fig. 2.-DASYATIS AKAJEI.

distance anterior to the caudal spine, which is placed about one-fourth distance from origin of tail; caudal spine of our specimen broken at tip, the basal portion without serrations.

Coloration above, purplish brown, becoming lighter toward edges of disc and posteriorly; tail like back; below uniform whitish.

This specimen differs a little from Dasyatis akajei, but is probably the young of that species.

\section{Measurements of specimen No. $7 \gamma x$.}

Length of disc, $210 \mathrm{~mm}$. Width of disc, $235 \mathrm{~mm}$. Tail, $420 \mathrm{~mm}$.
Snout, 0.26 .

Interorbital width, 0.13.

Ventrals, 0.20.

The proportional measurements are based on length of disc as the unit of comparison. 


\section{Family SILURIDÆ.}

\section{GLANIS ASOTUS (Linnæus).}

Anal fin united to the caudal.

Head 5; depth 5.25; snout 3.3 in head; eye 3 in snout; interorbital 2.5 in head. D. 4; A. 81; P. I, 12; V. 11; C. 16 . Body spindle-shaped, anteriorly depressed and posteriorly compressed; body deepest a little posterior to dorsal, from which point it slopes obliquely down to the broad depressed snout; mandible depressed like the snout, projecting; body posteriorly depressed and tapering gradually to the tail; interorbital space flat; a well-marked median dorsal groove from occiput to middle of anal.

Teeth in broad villiform bands in both jaws and in a broad continuous band on vomer; maxillary barbels long, reaching past end of ventral spine; mandibular tentacles short, equaling interorbital width; eye small, diameter 4 times in interorbital width; snout short, rounded, 3.3 in head; lateral line following outline of back, continuous from above opercle to base of caudal.

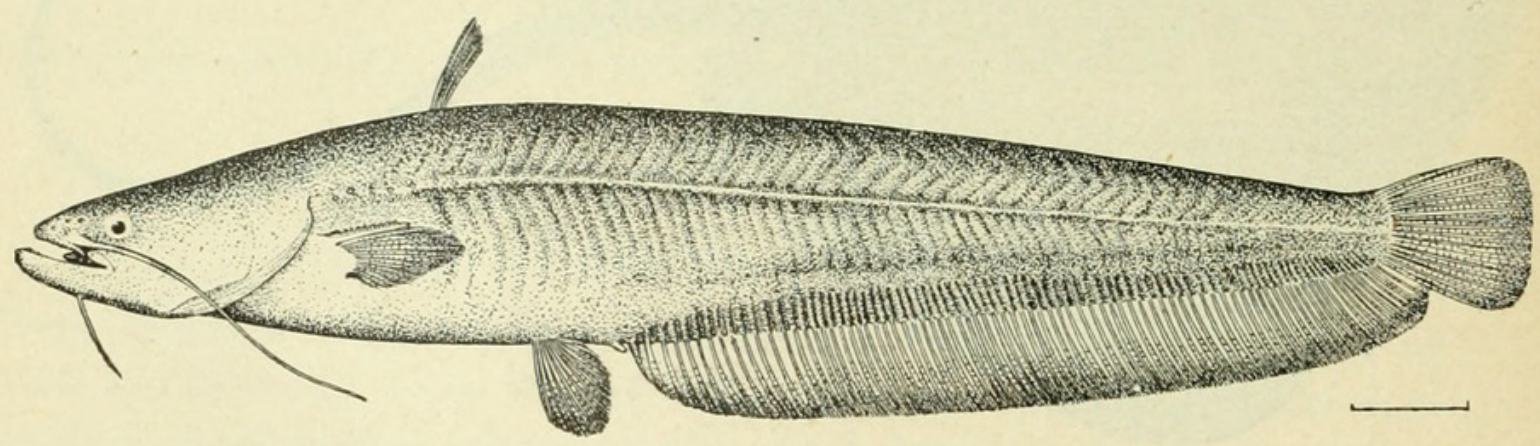

Fig. 3.-GLANis asotus.

Dorsal short, of 4 rays, placed about midway between insertion of pectorals and ventrals, height about 3 in head; pectoral inserted below angle of opercle, the longest rays reaching slightly past vertical from dorsal; pectoral spine strong, serrated on outer edge, length equal to height of dorsal; ventrals situated before anus, obtusely pointed, longest rays exceeding pectoral spine; anal long, beginning at anus and extending to the caudal to which it is united, height equal to that of dorsal; caudal 2 in head, truncate.

Coloration above, brownish-olive; fins, the same; below, yellowishwhite, the mandible, sides below pectoral, and breast along gill-openings finely brown-spotted.

One specimen, 12 inches long, from Formosa, without indication of locality, but doubtless from the Tan Sin River at the capital, Taihoku. The generic name Glanis Agassiz is equivalent to Parasiturus Bleeker.

ro. PLOTOSUS ANGUILLARIS (Bloch).

One specimen, No. 12071, from Giran. 


\section{C.HLARIAS FUSCUS (Lacépède).}

Two specimens, Nos. 6446, from Taihoku, and 5060 from Formosa, F. I The first has P. I., 9; A. 43.

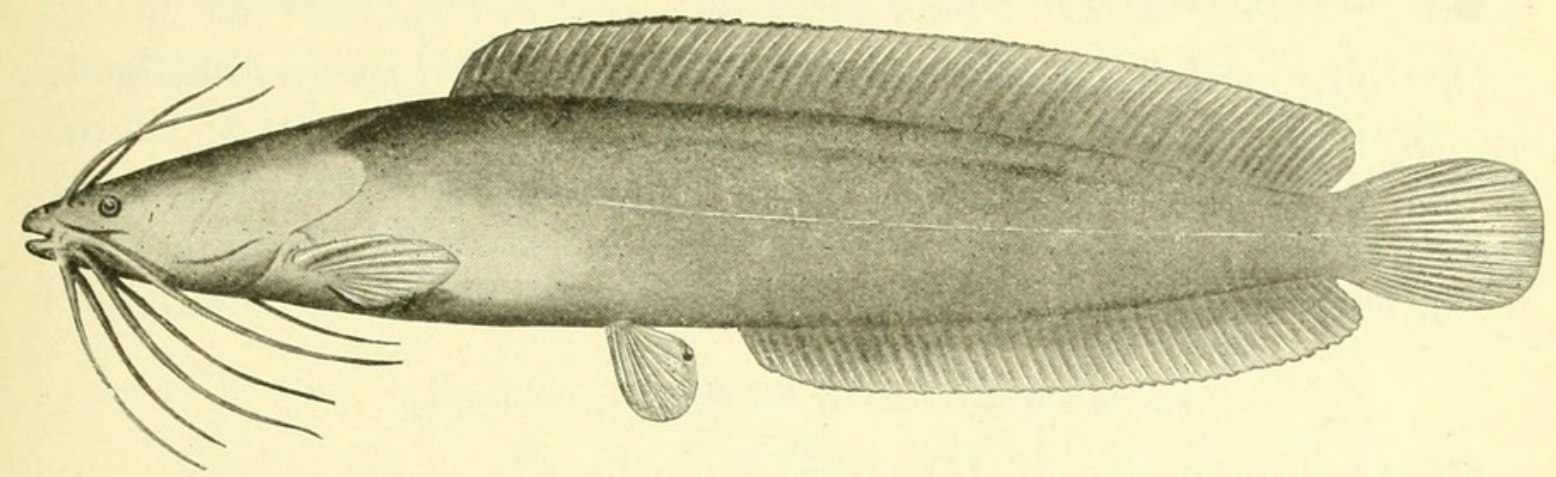

Fig. 4.-Chlarias fuscus.

I2. TACHYSURUS SINENSIS Lacépède.

One specimen, No. 6171, F. I., with the dorsal and pectoral spines somewhat shorter and the palatine patches of teeth more rounded than in the published figures, otherwise agreeing. A young example, No. 12075, Suwata, is an immature representative probably of the same species.

I3. TACHYSURUS FALCARIUS Richardson.

One specimen, No. 6171; Suwata.

\section{Family COBITID A.}

I4. MISGURNUS ANGUILLICAUDATUS Cantor.

Two specimens, No. 5065, from Taihoku: one 57x, Formosa, F. I.

\section{Family CYPRINIDA.}

I5. CYPRINUS CARPIO Linnæus.

One specimen, No. $875=53 x$, Formosa, F. I.

\section{r6. CARASSIUS AURATUS (Linnæus).}

Giran; Taihoku, No. 3830, Formosa, F. I.; No. $866=57 x$, Formosa F. I.

\section{I7. ROHITA DECORA (Peters)}

One specimen, No. $3837=57 x$, Formosa, F. I., 162 mm. long.

D. 16 , its first rays unbranched; A. 9, its first rays very small, the 7 posterior rays branched; P. 19; C. 20 ; scales 40; pharyngeal teeth $5-4,2$; head 5.5 in length; depth 3.2 ; eye 3.3 in head; no maxillary barbels.

The generic name Rohita should take the place of Labeo which is Proc, N. M. vol. $\mathrm{xxv}-02-21$ 
preoccupied in Sparidx by Labeo Bowdich, 1825= Boops Cuvier, 1817. Labeo sparoides Bowdich, Exc. Madeira, 1825, p. 122, fig. 59, is identical with Boops boops (Linnæus).

18. CTENOPHARYNGODON IDELLUS (Cuvier and Valenciennes).

One large specimen, $355 \mathrm{~mm}$. long, agreeing fairly with Günther's description. Head 4.3; depth 3.3; pharyngeal teeth 2, 5-4, 2; D. 10; A. 11 ; V. 10 ; P. 20 ; scale $6-41-4$ (to ventrals); depth 3.8 in length; head 4.4 .

No. $56 \mathrm{x}=5061$, from Formosa, F. I., doubtless from Taihoku.

I9. HEMIBARBUS BARBUS (Schlegel).

Head 3.5 in length; D. III, 7; A. 9; scales 47 .

No. $57 \mathrm{x}=867$, Formosa, F. I.

Also recorded from Formosa by Günther. It is similar to specimens from Osaka, except that the snout is a little longer and the dorsal spine stouter.

2o. CULTER BREVICAUDA Günther.

Head 4.25; depth 3.25; D. II, 7; A. 28; scales 67; teeth 5, 4, 1-4, 4, 2.

No. $55 \mathrm{x}=865$, F. I. The species was originally described from Formosa.

2I. CIRRHINA, species.

Closely allied to Cirrhina chinensis Günther. D. 15; A. 7; scales 37 ; teeth 5, 4, 2.

No. 837 , Formosa, F. I.

22. ZACCO PACHYCEPHALUS (Günther).

D. 9 ; A. 12; scales 53; Head 3.25; depth 3.5; pharyngeal teeth 5, 3, 1; four scales between lateral line and ventrals.

No. 12076, Suwata; 12232, Taihoku. The species was originally described from Formosa, collection of Consul Swinhoc.

The new generic name Zacco Jordan and Evermann (Zakko, a minnow, in Japanese) may be applied to the group of which platypus is the type. It differs from Opsariichthys in lacking the peculiar notched jaws of the type (uncirostris) of that genus. The anal fin in Zacco is much elevated in the males, which are also highly colored (blue and crimson) in the breeding season, the head covered with warts.

23. ZACCO EVOLANS Jordan and Evermann, new species.

Two specimens, No. 877, F. I., and 12231, Taihoku, agree fairly with ordinary Japanese specimens except in the much greater length of the pectorals. Scales 45; pectorals reaching ventrals; anal lobe past front of caudal. Body with about twelve dark cross-bars. 
Head 4.25; depth 4.25; eye 3.2; snout 4; interorbital 3; D. 9; A. 11; scales 9-47-4. Body short and very greatly compressed; back somewhat arched; head moderate, mouth rather large, slightly oblique, the jaws subequal, the snout rather pointed; scales very thin, cycloid, lateral line running very low; jaws and cheek with a number of phosphorescent spots; origin of dorsal nearer tip of snout than base of caudal, the fin very high, its rays greater than length of head; caudal forked; anal fin very large, the rays nearly twice the length of head; ventrals short, reaching origin of anal; pectoral long and falcate, half longer than head, reaching middle of ventrals.

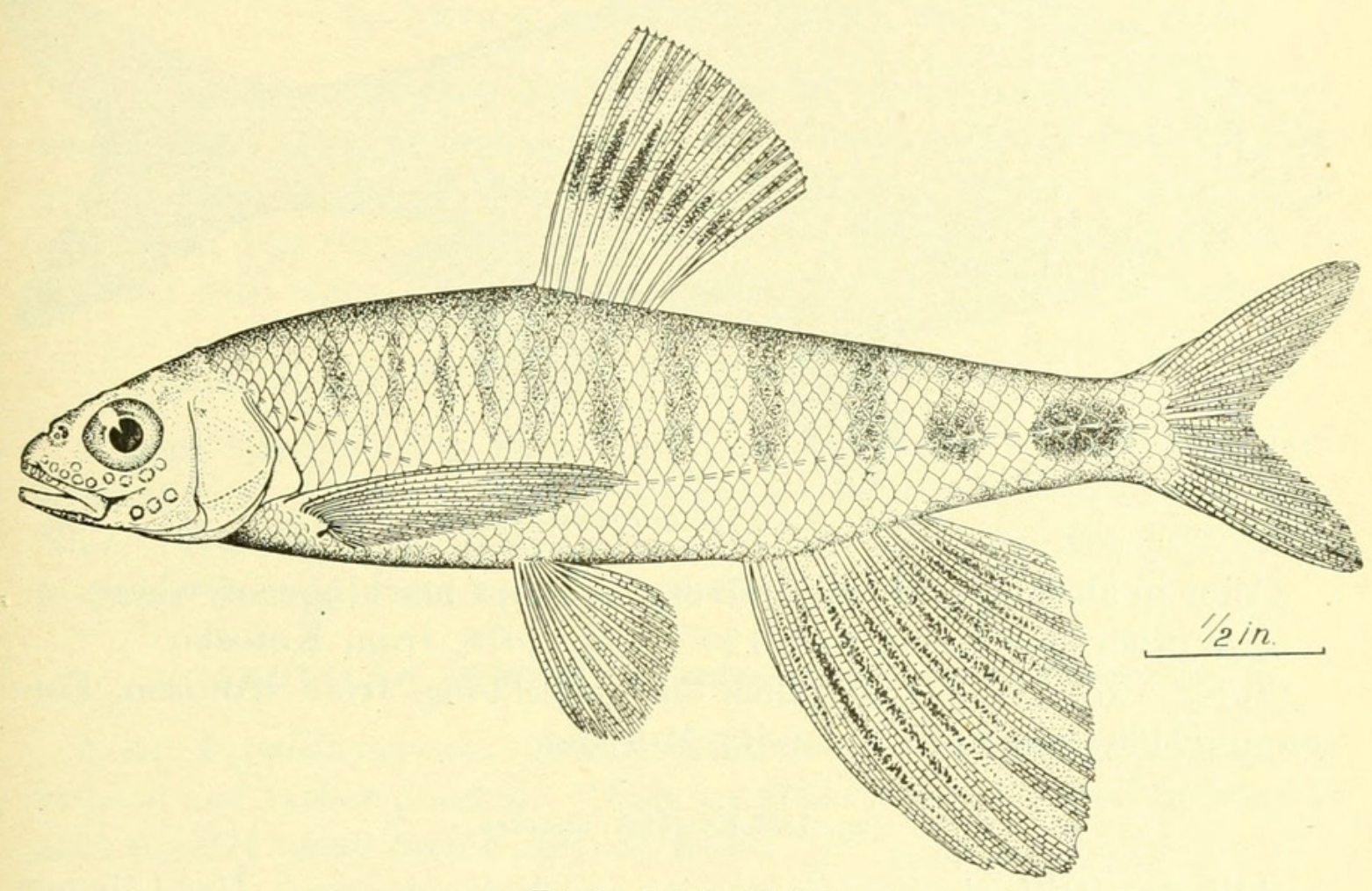

FIG. 5.-ZACCO EVOLANS

Color in alcohol, silvery-olivaceous above, the side with about eleven broad, dark, plumbeous cross-bars, suggesting the parr marks in a young trout; membranes of dorsal fin dark brown or almost black near center of fin; membranes of anal fin dark; other fins pale.

Type.-No. 12230, a specimen 3.5 inches long, from Taihoku. This is numbered 7129 Stanford University Museum.

24. ACHEILOGNATHUS MESEMBRINUM Jordan and Evermann, new species.

Head 4; depth 2.8; eye 3.5 ; snout 4 ; maxillary 3 ; mandible 2.5 ; interorbital 2.5 ; D. 8 ; A. 15 ; scales 8-38-5.

Body short, deep, and very greatly compressed, bearing some resemblance to the American species called Cyprinella; head small and pointed; mouth moderate, somewhat oblique, the jaws subequal, maxillary reaching anterior edge of orbit; scales large and well imbricated; lateral line running low, gently decurved under front of dorsal, and 
passing along lower third of caudal peduncle; origin of dorsal slightly nearer tip of snout than tip of caudal fin; the fin high, its anterior rays nearly equaling head in length; base of anal oblique, the free edge somewhat concave, the longest rays 1.3 in head; caudal fin lunate; ventrals and pectorals moderate, the latter falcate.

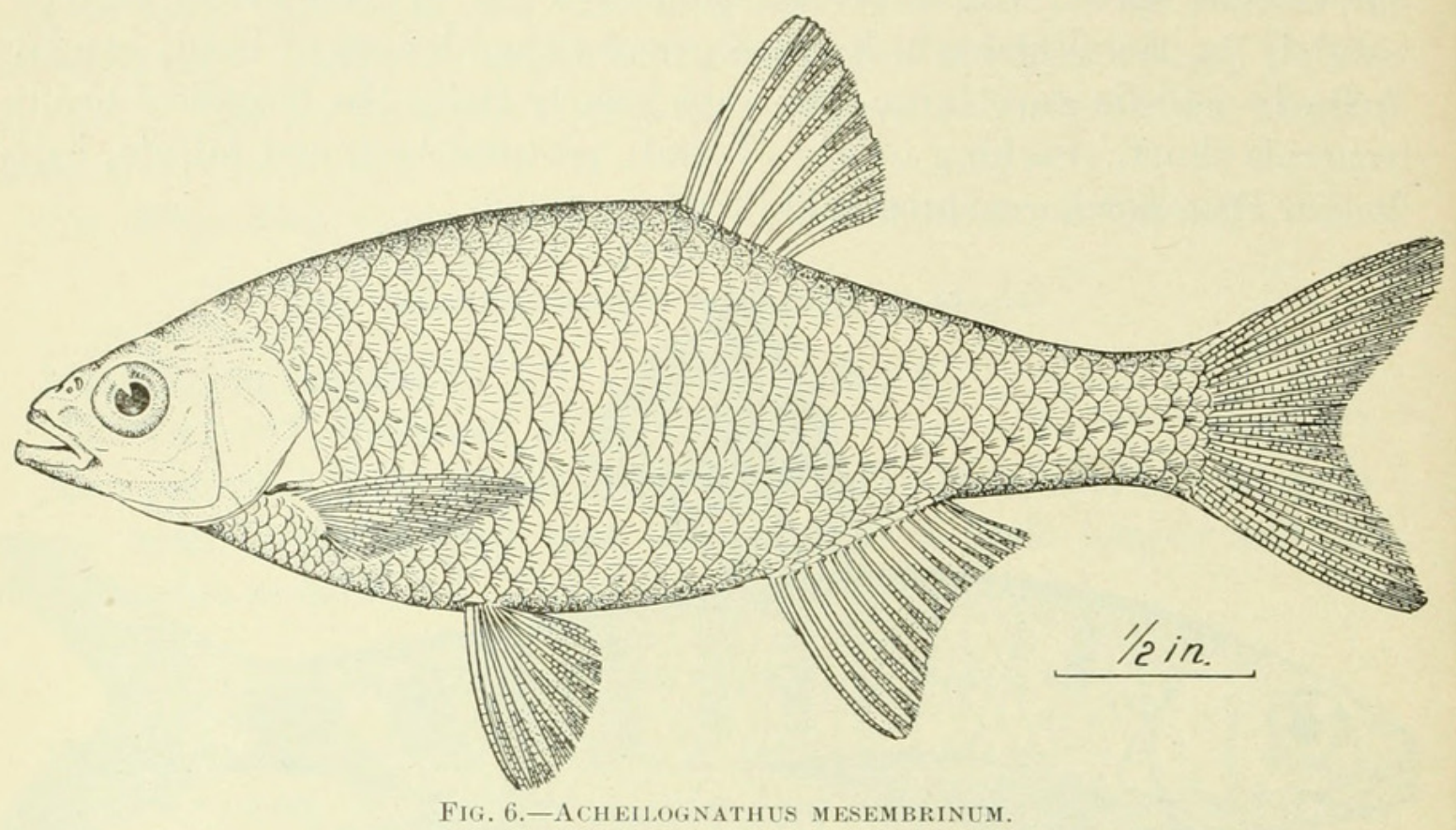

Color in alcohol, yellowish-silvery, without markings anywhere. Two other specimens, Nos. 12072 and 12078, from Kotosho.

Type.-No. 12235, a specimen 3.5 inches long, from Kotosho, Formosa $=7130$ Stanford University Museum.

25. DiLLONIA, species.

Allied to Dillonia aculata Cuvier and Valenciennes. Head shaped as in Scaphiodon. Mandible with barbels; D. 10; A. 11; scales 39.

The specimen of this species from Formosa has been mislaid, and nothing more can be said of it at present.

\section{Family MONOPTERIDA.}

26. MONOPTERUS ALBUS (Zuiew).

Head 10.5 ; tail 3.5 in rest of body; No. 12066, F. I.

In another specimen, perhaps not the same species (No. 6448, Hokoto), the tail is a little longer, more than one-third rest of body, and the head 11.5 in length. Much more material is necessary to ascertain whether more than one valid species of Monopterus exists. 


\section{Family ANGUILLID E. \\ 27. ANGUILLA MANILENSIS (Bleeker).}

One specimen, No. 1590, from Kotosho. Maxillary teeth in two bands, separated by a longitudinal division, as in A. bengalensis; eye large, the cleft of the mouth extending to just below posterior edge of pupil; head somewhat less than distance between front of dorsal and anal; pectoral broad, dark; coloration mottled. This specimen agrees fairly with Bleeker's figure of Murzena manilensis.

\section{ANGUILLA MAURITIANA Bennett.}

Distance from front of anal to front of dorsal much greater than head; pectoral 2.7 in head; head short, about equal to distance from gill-opening to dorsal fin; eye small, cleft of mouth extending to beyond it; lips very thick; anterior nasal tubes prominent; body much mottled with black. A large specimen, No. 12073, from Kotosho.

29. ANGUILLA SINENSIS McClelland.

A small specimen, No. 6447, from Taihoku. It agrees with Günther's account of $A$. latirostris, but that species was originally described from Nice. The long head, greater than the distance from front of dorsal to front of anal, is characteristic of this species.

30. ANGUILLA REMIFERA Jordan and Evermann, new species.

Near Anguillajaponica Schlegel, but the pectoral much longer, 2.17 in head and rather pointed. Distance from front of dorsal to front of anal slightly more than length of head.

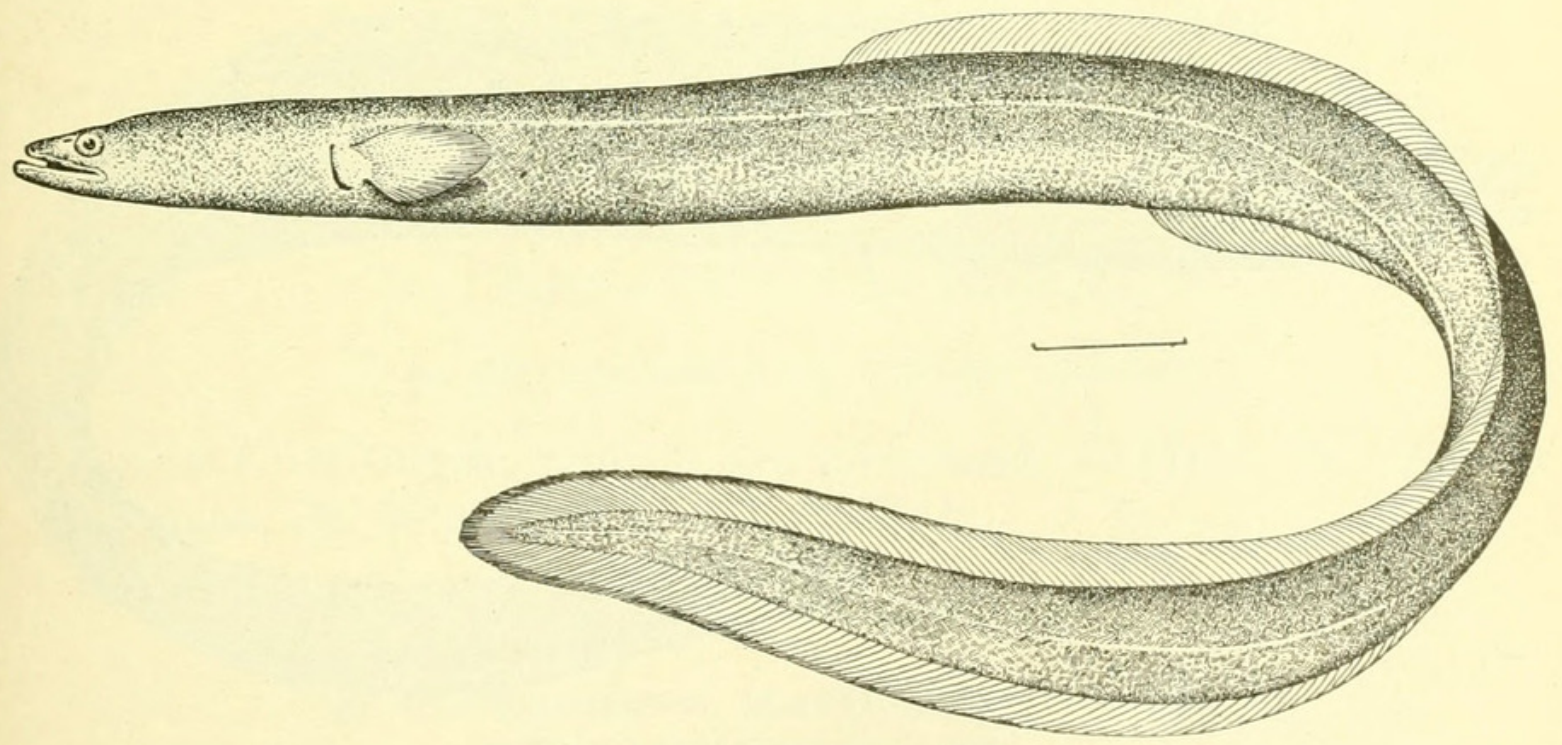

Fig, 7.-ANGUILLA REMIFERA.

One specimen, No. 12064 (70), 18.5 inches long, from Hokoto, Formosa, returned to the Imperial University. 
Head 9 ; depth 18; eye 10.5; snout 6 . Distance from snout to origin of dorsal less than one-third total length; anal origin about two-fifths total length from tip of snout; dorsal and anal confluent around caudal; pectoral 2 in head; gill-opening small; lower jaw slightly projecting; teeth strong.

Body long and slender, little compressed, except posteriorly; head long, pointed. Color in alcohol, grayish-olive, paler below; caudal and posterior portions of dorsal and anal edged with black.

\section{Family LEPTOCEPHALIDA.}

\section{LEPTOCEPHALUS, species.}

One ribbon-shaped larva of some eel or eel-like fish, probably a Conger, but not certainly identifiable.

\section{Family OPHICHTHYID AE.}

32. PISOODONOPHIS BORO (Hamilton-Buchanan).

No. 1591, Toii, and No. 12065, Formosa, F. I.

\section{OPHICHTHUS CEPHALOZONA Bleeker.}

A small specimen agreeing with $O$. cephalozona in most regards, but the dorsal is lower and the pectoral shorter, 4.7 in head. The coloration is obscure, the body being crossed by obscure paler bands; the markings on the head as figured in O. cephalozona. Apparently these variations are due to the immature condition of the specimen.

No. 6449, Hokoto.

Family MURANID A.

34. GYMNOTHORAX PESCADORIS Jordan and Evermann, new species.

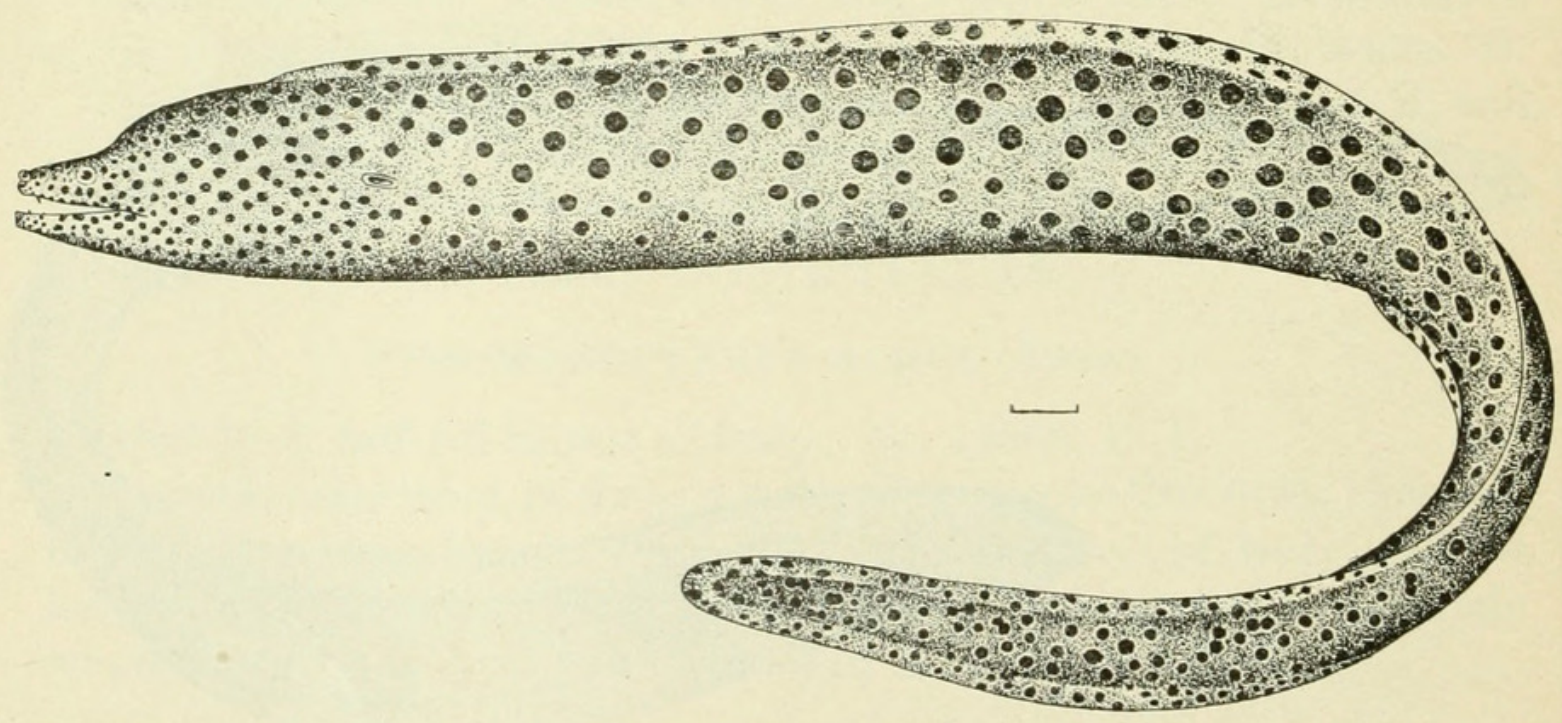

FIG. 8.-GYMNOTHORAX PESCADORIS

Teeth uniserial on sick of each jaw; two large, sharp, movable teeth on median line of roof of mouth; eye 2.25 in snout, in anterior half of gape; tail slightly shorter than rest of body. 
Color in alcohol, dark olive-brown, covered profusely everywhere with large, roundish, jet-black spots, these largest and most numerous on back and sides, more sparse on belly; spots of jaws and head less regular in shape and very numerous, the interspaces being more nearly white.

Type.-No. 6450, 40 inches long, from Hokoto or Pescadores Islands, No. 7131, Stanford University Museum.

\section{EVENCHELYS MACRURUS (Bleeker).}

Second series of mandibular teeth fewer than as described; posterior vomerine teeth fewer.

A fine specimen, 6.25 feet in length, No. 12063, from Kotosho.

The new genus Evenchelys Jordan and Evermann (type, macrurus) differs from Gymnothorax in the excessively long tail, which is nearly twice the length of the rest of the body.

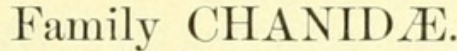 \\ 36. CHANOS CHANOS (Forskål).}

D. $14 ;$ A. 9 ; scales 92 .

Several young examples, Nos. 12067 (Giran), 12238 (Taihoku), 11435, F. I., 12083 , F. I., and 876 F. I.

One specimen from Toii.

\section{Family ELOPIDA:}

37. ELOPS MACHNATA Rüppell.

D. 20 ; A. 14 ; V. 14; Nos. 12236, Formosa, F. I., and 12237, from Suwata.

\section{MEGALOPS CYPRINOIDES (Broussonet).}

D. I, 8; A. 24; scales 39 .

Head 4 in length; depth 3.5. Nos. 871 (Formosa), F. I., and 12069 (Giran).

\section{Family CHIROCENTRID A.}

\section{CHIROCENTRUS DORAB (Forskål).}

Head 6.5 in length; depth 7; eye 4.5 in head: D. 17; A. 30. A large specimen, No. $87 \mathrm{x}=868$ (Formosa), F. I.

\section{Family DOROSOMIDAE.}

\section{CI.UPANODON MACULATUS (Richardson).}

Head 3.7 in length; depth 2.75; D. 16; A. 25; scales 48. Dorsal not inserted much before ventrals; no black spot on shoulder. No. 12068 (Giran). Recorded by Günther from Formosa. 
4I. CLUPANODON NASUS (Bloch).

D. 17; A. 20; scales 49. Nos. $870,878=77 \times$ (Formosa), F. I., 12074 (Giran), and 12084 (Kotosho).

\section{Family CLUPEID A.}

42. SARDINELLA TOLI (Cuvier and Valenciennes).

D. 18; A. 20. Nos. 12077, and 12085 (Kotosho).

43. ILISHA ELONGATA (Bennett).

Head 3.7; depth 3.3; D. 16; A. 44; V. 5; scales 50,-13; 24 scutes before vent, 12 behind. No. 872 (Formosa), F. I., a very large example.

44. DUSSUMIERIA ELOPSOIDES Bleeker.

Head 4.3 ; depth 6 ; D. 19 ; A. 16 ; P. 15 .

No. 11343 (Kotosho), in bad condition.

Family ENGRAULIDA.

45. ANCHOVIA INDICA (Van Hasselt).

(Engraulis russelli Bleeker.)

Head 4.5; depth 5.75; D. 16; A. 20; P. 13.

Two specimens, Nos. 12233, F. I., and 12234 (Suwata).

Family SALMONIDA.

46. Plecoglossus ALtivelis Schlegel.

Head 4.75; depth 4.75; D. 11; A. 17; V. 8; scales about 133.

Nos. 3832, 3833, and 3834, Taihoku.

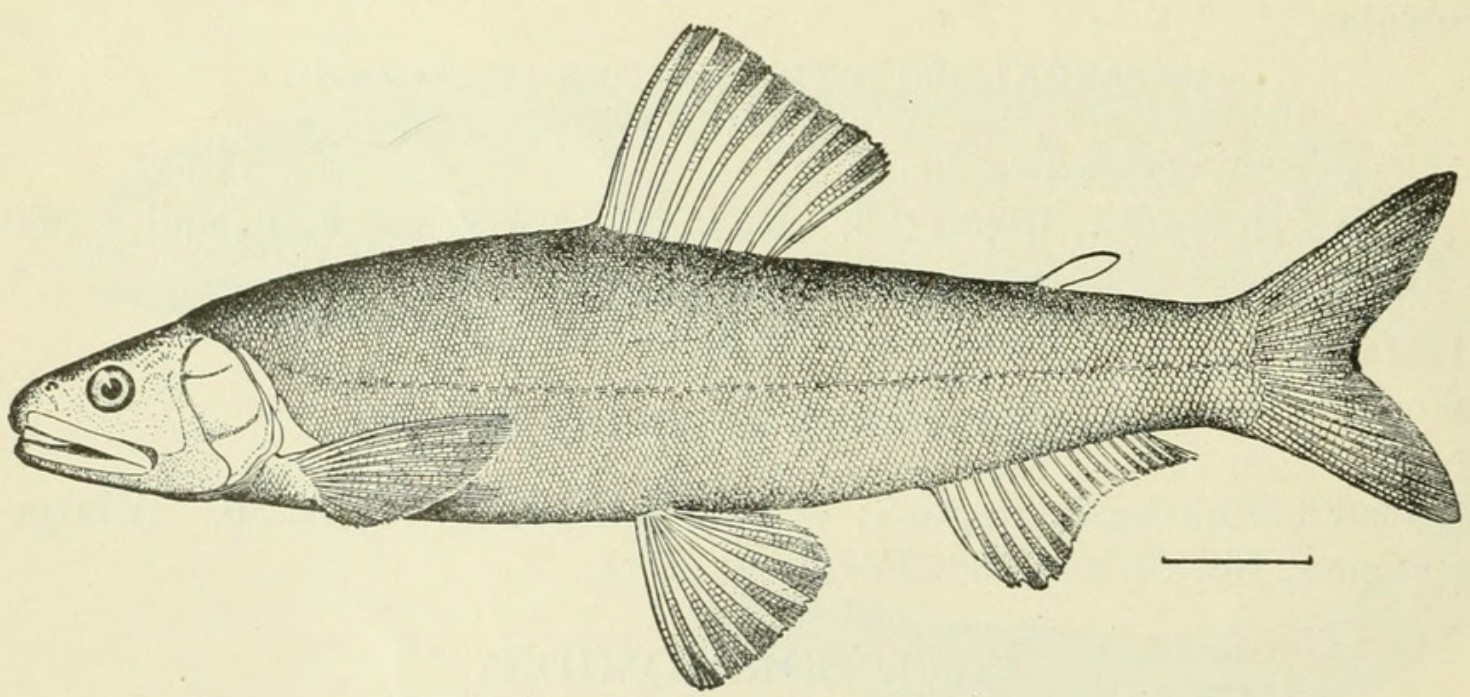

Fig. 9.-Plecoglossus altivelis.

These specimens agree with those of the common Ayu of Japan, except that the anal fin is slightly longer, its length being 1.17 in herd, nearly twice its longest ray. This difference is doubtless due to their large size, and probably has no taxonomic value. 


\section{Family SYNODONTID A. \\ 47. SAURIDA ARGYROPHANES (Richardson).}

D. 12 ; A. 11 ; scales 52 to 54 .

Nos. 11326 and 3836 (Formosa), F. I.

This species is quite different from the Japanese Saurida japonica, having the eyes scarcely veiled by the very narrow or adipose eyelid, and the pectoral fin much longer, 1.6 in head, reaching to or beyond front of pectoral. Saurida japonica (Wakanoura, Japan) has the pectoral 1.6 in head, not reaching ventrals and reaching about to the eighth scale of lateral line. Head 4.5 in length in Saurida argyrophanes; about 5 in Saurida japonica.

\section{TRACHINOCEPHALUS TRACHINUS (Schlegel).}

One specimen from Keerun.

\section{Family BELONIDA.}

49. TYLOSURUS LEIURUS (Bleeker).

Head 3.25 in length; depth 17 ; D. 19 ; A. 24; eye 2.5 in postorbital part of head. Length of pectorals much greater than depth of body, equal to postorbital part of head; no gillrakers.

No. $5059=62 \times$ (Formosa), F. I.

\section{TYLOSURUS MELANOSTIGMA (Cuvier and Valenciennes).}

Head 3.75 in length; depth 14 ; D. 25 ; A. 27 ; eye 2.25 in postorbital part of head; no dark blotches on sides.

No. 3835 (Formosa), F. I.

\section{Family NEMIRAMPHID AE. \\ 5I. HEMIRAMPHUS FAR (Forskål). \\ (Hemiramphus commersoni Cuvier).}

Head 4.5 in length; depth $5.75 ;$ D. 13 ; A. 11; side with a silvery band and 4 dark spots.

Nos. 11329, 11330, 11436 (Formosa), F. I.

\section{HEMIRAMPHUS GEORGII Cuvier and Valenciennes}

Head 4.5 in length; depth 7.5; eye 1.75 in postorbital region; D. 14; A. 13 ; scales 50 .

Nos. 875 and $879=54 \mathrm{x}$.

53. EULEPTORAMPHUS LONGIROSTRIS uvier.

One large specimen, No. $3835=17 \times$ (Formosa), F. I. 


\section{Family EXOCCETIDA.}

\section{CYPSILURUS SPILONOTOPTERUS (Bleeker).}

Head 4.75 in length; depth 5.5; D. 14; A. 10; scales 50. Pectorals black within; dorsal with a black blotch; second pectoral ray divided; ventrals white.

No. $3838=14 x$ (Formosa), F. I.

\section{Family FISTULARIID $\approx$.}

55. FISTULARIA PETIMBA (Lacépède).

Head 2.75 ; snout 3.75 ; D. 16 ; A. 12.

One large example, No. 11437 (Formosa), F. I.

\section{Family OPHICEPHALID A.}

56. OPHICEPHALUS MACULATUS (Lacépède).

One specimen, No. 38x (Formosa), F. I.

A. 26 ; scales 53 .

One specimen, No. 5096, from Giran.

57. OPHICEPHALUS TADIANUS Jordan and Evermann, new species.

Head 3 ; depth 4.75 ; eye 8.6 ; snout 6.2 ; maxillary 2.65 ; mandible 2.3 ; interorbital 5.3; D. 42 ; longest dorsal ray 3 ; A. 26 ; longest anal ray 2.7 ; ventrals 3.5 ; pectoral 2.3 ; scales $6-57-11$. Body spindleshaped, compressed posteriorly, caudal peduncie short, deep and greatly compressed; head long and snake-like, covered with plate-like scales; eye small, anterior; nostrils wide apart, the anterior in a small tube on upper edge of maxillary; mouth oblique, large, the maxillary reaching past orbit; a band of small teeth on outer edge of jaws, a band of large, wide-set, canine teeth on palatines and inner side of lower jaw; upper jaw protractile; dorsal long, of numerous spinelike rays, low anteriorly, gradually lengthening posteriorly; caudal rounded; anal similar to dorsal, but not so long; ventrals very small and short, not reaching vent; pectoral short and rounded; lateral line broken anteriorly, running along center of body from base of caudal to just over second anal ray, thence upward for 2 rows of scales, then forward for 15 rows of scales, thence downward for 1 row, then forward to upper edge of gill-opening, where it ends.

General color in alcohol, olivaceous-brown above, lighter below; belly white, with some yellowish markings; a row of 12 dark olivaceous blotches along base of dorsal, partly on fin and partly on body; below these but above lateral line another row of 8 or 9 similar but larger blotches, extending anteriorly to the middle of upward curve in lateral line; below this another line of about 13 lighter colored and 
very irregular blotches, extending from base of pectoral posteriorly along lower edge of lateral line to base of caudal: below this another line of scattered and faint blotches from lower edge of pectoral to posterior end of anal; head color of upper part of body, but streaked with irregular lines of black above; a line of light dusky, as wide as pupil, but becoming nearly as broad as eye at edge of opercle, running from posterior edge of eye to base of pectoral, its lower edge just below upper base of pectoral; below this an irregular line of light brown-olivaceous slightly wider than pupil, running to middle of base of pectoral; head below this pale: dorsal with 2 broken stripes of brown-olivaceous about as wide as pupil; caudal membranes dark, rays pale brown-olivaceous, anal with indications of 4 or 5 dark

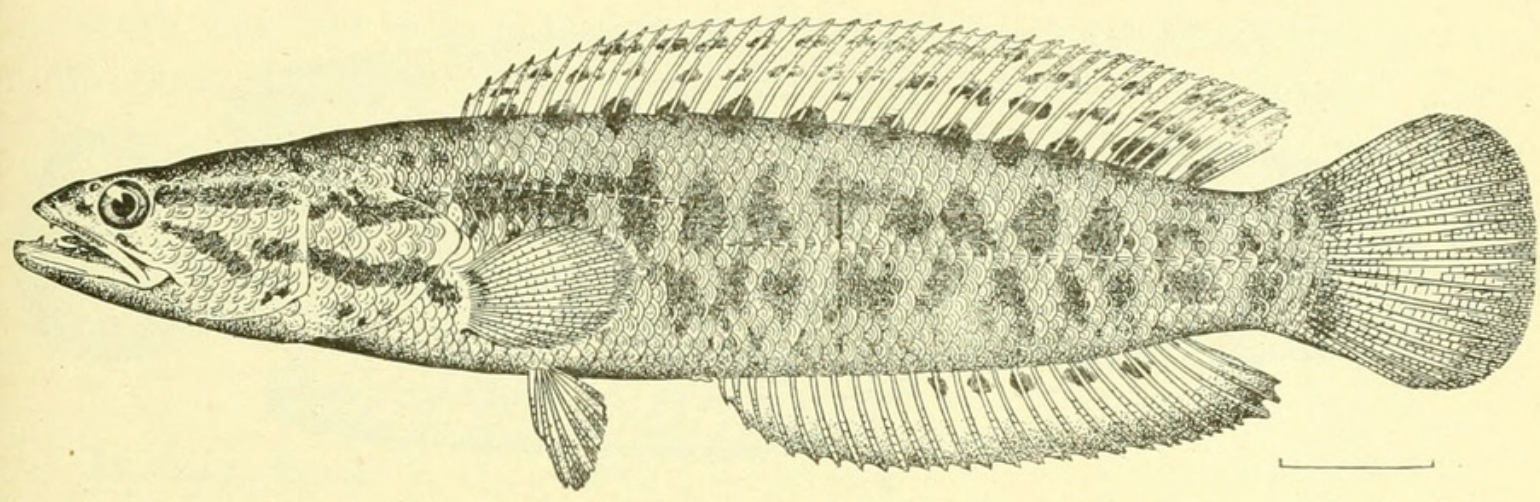

Fig. 10.-OPHIOCEPHALUS TADIANUS.

blotches at the base of posterior half, rest of fin pale at base, becoming darker, almost brown-olivaceous toward tips; ventrals pale, dusky; pectoral slightly darker than ventrals.

Type.-No. 3xx, a specimen 9.5 inches long, from Formosa, returned to the Imperial Fisheries Institute.

58. CHANNA FORMOSANA Jordan and Evermann, new species.

Head 3.6 ; depth 5.75 ; eye 5.75 ; snout 5.25 ; maxillary 2.5 ; mandible 2.25; interorbital 3.5; D. 44; A. 28; scales 4-54-13. Body moderately long and slender, much compressed posteriorly; head large, broad, depressed and snake-like; mouth large, oblique, the lower jaw slightly projecting, the maxillary reaching posterior edge of orbit; teeth cardiform, in both jaws and on vomer; eye moderate; caudal peduncle short, very deep and very much compressed. Scales large, plate-like, each with strong concentric striæ; lateral line very irregular, beginning above opercular opening, extending backward on 7 scales, then running for 8 scales on next row above, then dropping irregularly for 3 or 4 rows over origin of anal, thence continued along median line of side to base of caudal fin. Dorsal fin long, beginning over base of pectoral, the rays quite uniform in length, the last being somewhat longest, being about 2.5 in head; anal similar to dorsal, but shorter, beginning under about the twelfth dorsal ray and ceasing 
under the last dorsal ray but two; rays of dorsal and anal all unbranched, but articulated; pectoral short and broad, its tip reaching vent; ventrals absent; caudal broad and rounded.

Color in alcohol, yellowish-brown, the side with about $8 \mathrm{~V}$-shaped imbricated dark crossbars, the apex pointing forward; these crossbars plainest posteriorly, more or less broken and irregular in front; a large, round, black ocellus on caudal peduncle at base of caudal fin as large as eye, bordered by white; side of head with two broad, dark bars extending from eye to posterior edge of opercle; dorsal fin punctulate but with about 2 series of rather distinct white spots on the membrane, extending nearly full length of fin; anal fin plain, somewhat dusky at edge; caudal and pectoral pale, slightly punctulate.

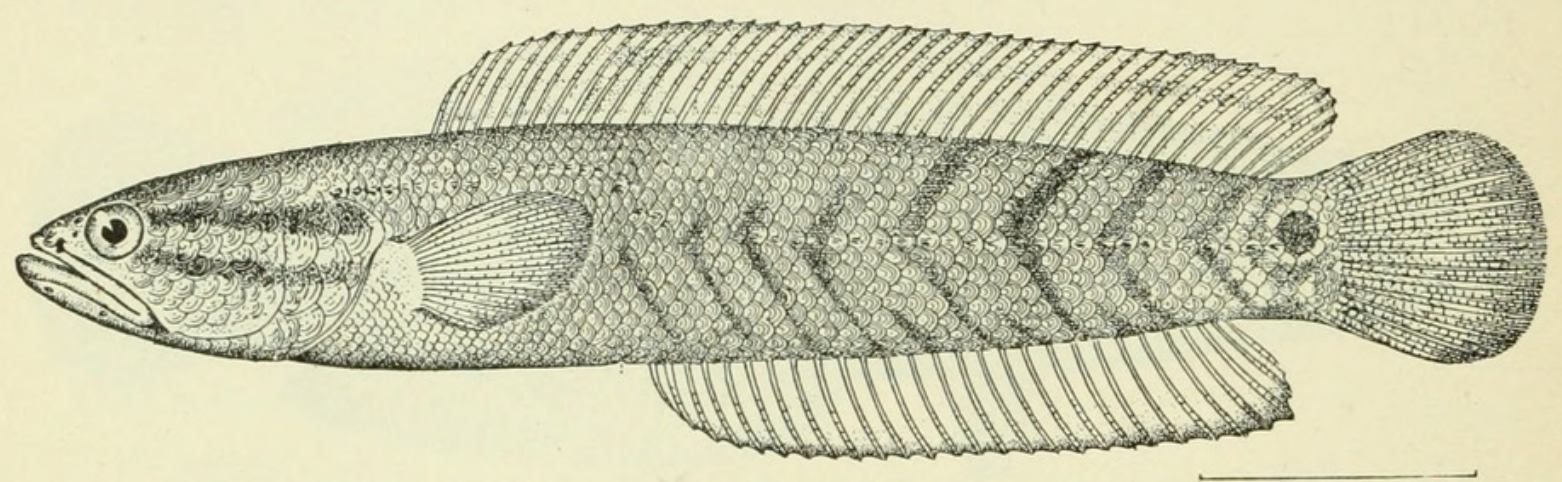

FIG. 11.-CHANNA FORMOSANA.

Type.--No. 5075, a specimen 5.25 inches long, from Sowo or Suwata, Formosa, now numbered 7132 Stanford University Museum; others, No. 269, are from Suwata.

\section{Family MUGILIDA.}

59. MUGIL OEUR Forskål.

(Mugil cephalotus Cuvier and Valenciennes.)

Several specimens, Nos. 5061, 5062 from Giran, 1589 from Keerun, 5067 from Taihoku, 377, 1064 (F. I.) from Formosa.

D. IV-I, 8; A. III, 8; scales 40,-12.

Dark streaks along scales more or less distinct.

6o. LIZA TROSCHELI (Bleeker.)

Head 4.1; depth 3.8 ; eye 3.75 ; snout 4.5 ; interorbital 2; D. IV-I, 8 ; A. II, 10; scales $30,-10$; body rather short and stout, the back gently and regularly arched from tip of snout to origin of spinous dorsal; head small, triangular, the interorbital broad and flat; eye rather large, snout short, the adipose eyelid small; teeth small but visible to the naked eye; sides of lower jaw meeting in a broad angle; lips thin; bare space between dentary bones club-shaped, broadest anteriorly, the subopercles overlapping below; pectoral broad and 
short, 1.5 in head; ventrals shorter than the pectoral, their length 2.5 times in distance from their base to origin of anal; first dorsal spine 1.75 in head; soft dorsal low, its longest ray 2 in head; origin of spinous dorsal slightly nearer base of caudal than tip of snout, or over tips of ventrals; caudal moderately forked, the lobes equal, their length equal to that of head; anal origin in front of soft dorsal, its free edge concave, its longest rays 1.75 in head.

Color in alcohol, grayish-silvery on side, dark olive on back and top of head; lower parts silvery-whitish; fins dusky, tips of middle caudal rays blackish.

One specimen, No. 5068, 9 inches in total length, from Hokoto, Formosa.

This specimen agrees with Mugil troscheli from the East Indies except that the head is wider, the interorbital space twice the eye, and the body deeper 3.75 to 3.8 in length, equal to length of head. These discrepancies are probably due to individual variations or to the immaturity of the original type.

\section{Family SPHYRANIDA.}

\section{6r. SPHYRÆNA JELLO Cuvier and Valenciennes.}

D. V-I, 9; A. I, 10; scales 17-135-23.

This is doubtless identical with Sphyræna jello, but the scales seem smaller, more than 125 in lateral line.

No. 11328 (Formosa), F. I.

62. SPHYRANA JAPONICA Schlegel.

D. V-I, 9; A. I, 9; scales 11-87-14.

Nos. $3831 ; 3839=33 x$ (Formosa), F. I.

\section{SPHYRANA FORSTERI (Cuvier and Valenciennes).}

Scales $110,-16$.

Nos. 3831, 880 (34x), Formosa, F. I.

These specimens agree fairly with Günther's account of this species, but the species of this genus need comparative study.

\section{Family AMMODYTID A.}

64. BLEEKERIA MITSUKURII Jordan and Evermann, new species.

Two specimens, Nos. 11340 and 11342, from Giran.

Near to Bleekeria kallolepis and B. gilli, but with smaller scales than either. It is not easy to see why Dr. Day ${ }^{1}$ should reject the genus Bleekeria, placing its species in Ammodytes. Bleekeria has wellformed and finely sculptured scales, as well as small teeth in the jaws. 
In Ammodytes there are no teeth and the scales are almost obsolete, the body being crossed by folds of skin. Ammodytes is subarctic in distribution, Bleekeria is tropical. Ammodytes has a much larger number of fin rays and doubtless of vertebræ also.

Head 4.6; depth 8.5 ; eye 5.2 ; snout 3.8 ; D. 42; A. 15 . Body long, slender, and somewhat compressed; head very long; mouth rather large, the lower jaw much projecting, a prominent point below; maxillary thin, slipping under the preorbital, reaching orbit. Scales small and firm; lateral line running high, about two scales below dorsal, on caudal peduncle suddenly dropping to middle of caudal fin; dorsal fin long and low, depressible in a groove, its origin over base of pectoral; anal short, terminating under last dorsal ray; pectorals short

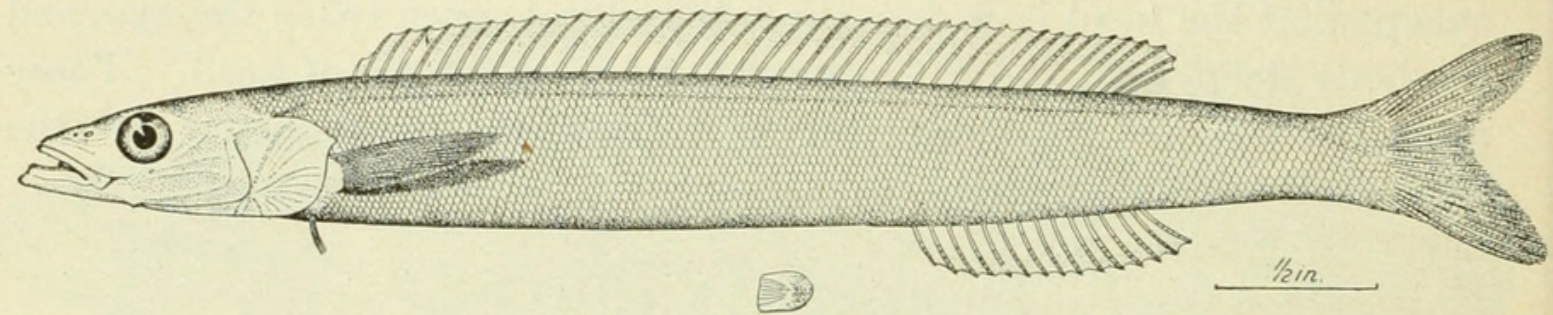

FIG. 12.-BLEEKERIA MITSUKURII.

and pointed; ventrals very minute, slightly in front of pectoral; opercular bones very thin and papery; teeth on front of jaws weak, apparently in villiform patches.

Color in alcohol, plain straw-yellow.

Type.-No. 11340 , a specimen 4.25 inches long, from Giran, now No. 7133, Stanford University Museum.

\section{Family HOLOCENTRIDA.}

- 65. OSTICHTHYS JAPONICUS (Cuvier and Valenciennes).

A large specimen, $1 \mathrm{x}$, Formosa, F. I.

The genus Ostichthys differs from Myripristis in the very rough scales and from Holotrachys in their very large size, larger than in any species of Myripristis.

Family MULLID A.

66. UPENEUS INDICUS (Shaw).

One specimen, No. 1592, from Keerun. Two dark streaks on second dorsal; golden area under first dorsal and dark blotch on caudal peduncle distinct.

One specimen, No. 302, from Giran. 


\section{UPENEUS CYCLOSTOMUS (Lacépède).}

\section{(Upeneus luteus Curvier and Valenciennes; Day.)}

One specimen, No. 273, from Keerun. It agrees fairly with Günther's account of $U$. cyclostomus and with Day's figure of $U$. luteus. In view of the doubt as to the synonymy of this species, we follow Günther in identifying it with Lacépède's Mullus cyclostomus.

\section{UPENEOIDES VITTATUS (Forskål).}

One specimen, No. 1756, from Keerun. Posterior black band on lower lobe of caudal very broad and black, the coloration unlike that of Hawaiian examples, supposed to be this species, the posterior band broader than in Day's figure. ${ }^{1}$

\section{UPENEOIDES BENSASI (Schlegel).}

One specimen, No. 275, from Keerun. Color, plain except for a dark tip to each dorsal, the color probably faded. Side with dark rivulate markings under each scale. Teeth all small, on jaws, vomer, and palatines. We identify this species with Upeneoides bensasi on the supposition that the color is faded. Such faded examples correspond to Upeneus subvittatus of Richardson. ${ }^{2}$ Probably the original subvit. tatus of Schlegel also is the same species. The latter has a banded caudal, as in Upeneoides bensasi.

Two small specimens, No. 314, from Kotosho are colored as in Japanese specimens of $U$. bensasi. Caudal with four dark bands on the upper lobe, the lower dusky with a whitish edge; first dorsal with three dark cross-bands, the second dusky at tip.

\section{UPENEOIDES TRAGULA (Richardson).}

Two specimens, Nos. 1755 and 358, from Keerun, agreeing with Day's figure. $^{3}$

Two specimens, Nos. 303 and 304, from Giran.

One specimen, No. 339, from Formosa, F. I.

One specimen, No. 281, from Hokoto.

Head 3.75; depth 4.2; eye 4; D. VIII-I, 8; A. I, 6; P. 13; scales 32.

\section{Family TRICHIURID A.}

\section{I. TRICHIURUS JAPONICUS Schlegel.}

One specimen, No. 5064, from Hokoto.

One large specimen, No. 17 x, from Formosa, F. I.

${ }^{1}$ Fishes of India, pli. xxx, fig. 2.

${ }^{3}$ Fishes of India, pl. $\mathrm{xxx}$, fig. 4.

${ }^{2}$ Ieth. China, p. 219, from Canton. 


\section{Family SCOMBRID E.}

72. SCOMBER JAPONICUS Houttuyn.

One small specimen, No. $27 \mathrm{x}$, from Formosa, F. I., of some mackerel, with low suborbital and rather elongate body. It may be Scomber janesaba Bleeker, but until these various Asiatic mackerel with air-bladders have been fully compared, we are not certain that any of them is separable from Scomber japonicus.

\section{SCOMBER KANAGURTA Russell.}

A small mackerel, No. $23 \mathrm{x}$, from Formosa, F. I., the body and especially the head deeper than in S. japonicus; the scales much more distinct, the color silvery, the dark markings less distinct. This corresponds fairly with Day's figure ${ }^{1}$ of the species he calls Scomber microlepidotus. This seems to be different from Scomber japonicus.

\section{GYMNOSARDA ALlETERATA (Rafinesque).}

One specimen, No. 26 x, from Formosa, F. I., in bad condition, the spots behind pectoral obsolete. The identity of this with the Atlantic species is questionable.

\section{SCOMBEROMORUS KUHLII (Cuvier and Valenciennes).}

One fine specimen, No. $21 \mathrm{x}=357$, from Formosa, F. I. Body without streaks or spots.

\section{Family CARANGID A.}

\section{SCOMBEROIDES ORIENTALIS (Schlegel).}

One specimen, No. 327, from Giran. This species seems to differ from Scomberoides toloo (=S. sancti-petri) in the elongate body, the depth being about 4 in length to base of caudal. The maxillary extends not quite to posterior margin of eye.

\section{MEGALASPIS CORDYLA (Linnæus).}

\section{(Scomber rottleri Bloch.}

A very large specimen, No. 18 x, from Formosa, F. I. Lateral plates extremely large, covering the posterior part of the body with a coat of mail, much larger than in any species of Carangus.

A fine large specimen, No. 370, from Formosa, F. I.

\section{DECAPTERUS MUROADSI (Schlegel).}

One specimen, No. 22 x, from Formosa, F. I. 
79. DECAPTERUS MACROSOMUS (Bleeker).

One specimen, No. 337, from Formosa, F. I. This species is distinguished by the large number of dorsal and anal rays, and the great development of the lateral plates, $49+38$, the latter number being that of the keeled plates on the straight part. There is a peculiar angulation of the lower part of the shoulder girdle approaching that in Trachurops.

A specimen of this species from Kagoshima, Japan, is in the Imperial Museum at Tokyo.

Orie specimen, No. 24 x, from Formosa, F. I.

80. TRACHUROPS TORVA (Jenyns).

One specimen, No. 352, from Formosa, F. I.; one specimen, No. $371=23$ x, from Formosa, F. I. ; one specimen, No. 325, from Giran; and one, No. 2070, from Giran.

\section{CARANGUS LEPTOLEPIS (Cuvier and Valenciennes).}

Two specimens, No. 297, from Keerun. Opercular spot very distinct, encroaching on the shoulder.

\section{CARANGUS MALABARICUS (Schneider).}

One specimen, No. 272, from Keerun. Dorsal lobe 1.4 in head; depth 2.12 in length (without caudal). Otherwise agreeing with Day's figure and Günther's description.

83. CARANGUS JARRA (Cuvier and Valenciennes).

One specimen, No. 274, from Keerun, referred with doubt to this species. The depth is 2.2 in length, the soft dorsal lobe 1.2 in head; D. VIII-I, 22. Lateral shields large, about 35 developed; breast naked; lateral line scarcely wavy.

\section{CARANGUS SEXFASCIATUS Quoy and Gaimard).}

One young example from Keerun. It agrees in essential respects with Carangus latus of the Atlantic. D. VIII-I, 20; plates 28 to 30; breast scaly; no distinct opercular spots; body with six broad faint cross-bands; first dorsal and tip of second blackish; anal pale. It agrees in general with Günther's account of Carangus hippos, but the true hippos is an American species, quite distinct (Carangus carangus of Günther).

\section{CARANGUS, species.}

A small specimen from Kotosho resembling Carangus jarra (Cuvier and Valenciennes). D. VIII-I, 23; scales about 30; no spots.

Proc. N. M. vol. $\mathrm{x} \times \mathrm{v}-02-22$ 
86. CARANGUS ARMATUS (Forskả1).

A large specimen, No. 17 x, from Formosa, F. I., with opercular spot and very high lobes to dorsal and anal fins.

One specimen, No. 21 x, from Formosa, F. I. Opercular spot present; lobes of dorsal and anal very low.

One specimen, No. 20 x, from Formosa, F. I. No opercular spot; produced anal ray as long as base of fin; ventrals pale.

This specimen corresponds to Cuvier and Valenciennes's figure of Carangus cirrhosus, but not to Olistus malabaricus, regarded by Günther as a synonym.

One large specimen, No. 349, from Formosa, F. I. Dorsal and anal lobes not extending much beyond middle of fin; opercular spot present.

\section{ALECTIS CILIARIS (Bloch).}

One specimen from Formosa, F. I., and two specimens from Keerun.

\section{Family LEIOGNATHID A.}

\section{LEIOGNATHUS EDENTULUM (Bloch).}

Head 3.3 in length; depth 1.7; second dorsal spine 1.3 in head. Two specimens, Nos. 279 and 297, from Formosa, F. I.

89. LEIOGNATHUS SPLENDENS (Cuvier and Valenciennes).

One specimen from Keerun and one fine specimen, No. 329, from Hokoto.

\section{9o. GAZZA EQUULÆFORMIS (Rüppell).}

One specimen, No. 317, from Kotosho. Depth 2.5 in length to base of caudal. Second dorsal spine about 2.7 in depth as in G. equulæformis. Axil black; spinous dorsal dusky anteriorly; some vague dark spots along lateral line.

One specimen, No. 328, from Hokoto.

\section{Family STROMATEIDA.}

\section{9i. APOLECTUS NigER (Bloch).}

A large specimen, No. 27 x, from Formosa, F. I. No ventral fins; caudal fin with a strong keel, suggesting that of Carangus, the scales on the keel thickened but without spines; color, pale grayish; gill openings very broad, the membranes not attached to the isthmus.

Head 3.8 ; depth 2.1 ; eye 5.6 ; snout 3.25 ; maxillary 3.4 ; mandible 3 ; interorbital 2.75 ; preorbital 10 ; D. 40; highest dorsal ray 1.1 ; A. 37 ; longest anal ray 1.3 ; scales about $27-97-50$, rubbed off and difficult to count; pectoral very long and narrow, 1.3 times the head. Body oblong-rhombic, greatly compressed, dorsal and ventral outlines con- 
siderably arched; dorsal profile from snout to origin of dorsal fin regularly curved; head moderate, the snout rather blunt; mouth moderate, somewhat oblique, the jaws subequal; maxillary broad, reaching front of orbit, slipping under preorbital for its entire length; teeth setiform, slender, and very weak in each jaw; top of head trenchant; nostrils oblong, very close together; eye moderate, partially covered by adipose membrane, slightly above level of upper lip; preorbital narrow. Cheek deep; edges of opercular bones membranaceous, the opercle-very thin and flexible; caudal peduncle depressed, and strongly keeled. Scales small, cycloid, somewhat irregularly placed; cheeks and opercles with fine scales; a large naked area from snout between eyes tQ occiput; dorsal and anal densely covered with thin scales;

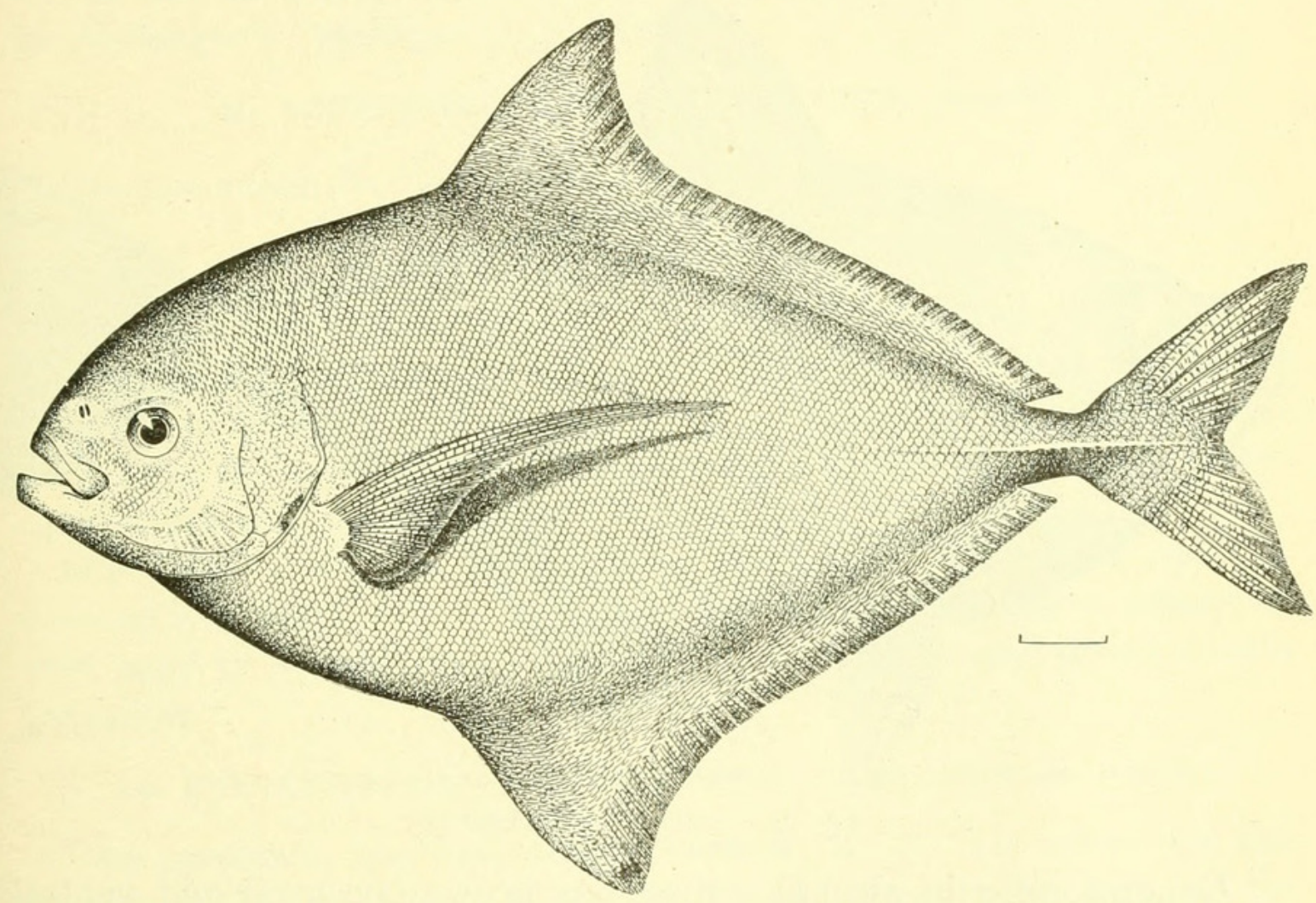

Fig. 13.-A POLECTUS Niger.

caudal with less complete squamation; dorsal fin elevated in front, distance of its origin from snout 1.4 in its base; anal similar to dorsal, its origin more posterior; caudal widely forked.

Color in alcohol, dirty yellowish-white, without markings, except a narrow black blotch on edge of opercle.

\section{Family PEMPHERIDA.}

92. PEMPHERIS NYCTEREUTES Jordan and Evermann, new species.

A single large specimen from Hokoto. It does not fit Dr. Döderlein's description of Pempheris japonicus very well, and the small size of the scales separates it still further from the others described. 
Head 3.4 ; depth 2.4; eye 2.5; snout 5.5; maxillary 2; mandible 1.75; interorbital 4; D. V, 9; longest dorsal ray 1.5 ; A. III, 44; longest anal spine 3.6, ray 2.8; scales 80 in lateral line; those above and below are rubbed off and not to be counted accurately. Body oblong, compressed; long base of anal very oblique; lateral line concurrent with the dorsal outline and extending to tip of tail; head compressed; eye large; snout very short, blunt; mouth large, very oblique; villiform teeth on vomer, palatines, and jaws; maxillary extending to below middle of eye; dorsal short, slightly behind ventral; anal very long, low and densely scaled at base; ventral spine as long as rays; pectoral broad, falcate, 1.2 in head; scales deciduous, those of lateral line most persistent.

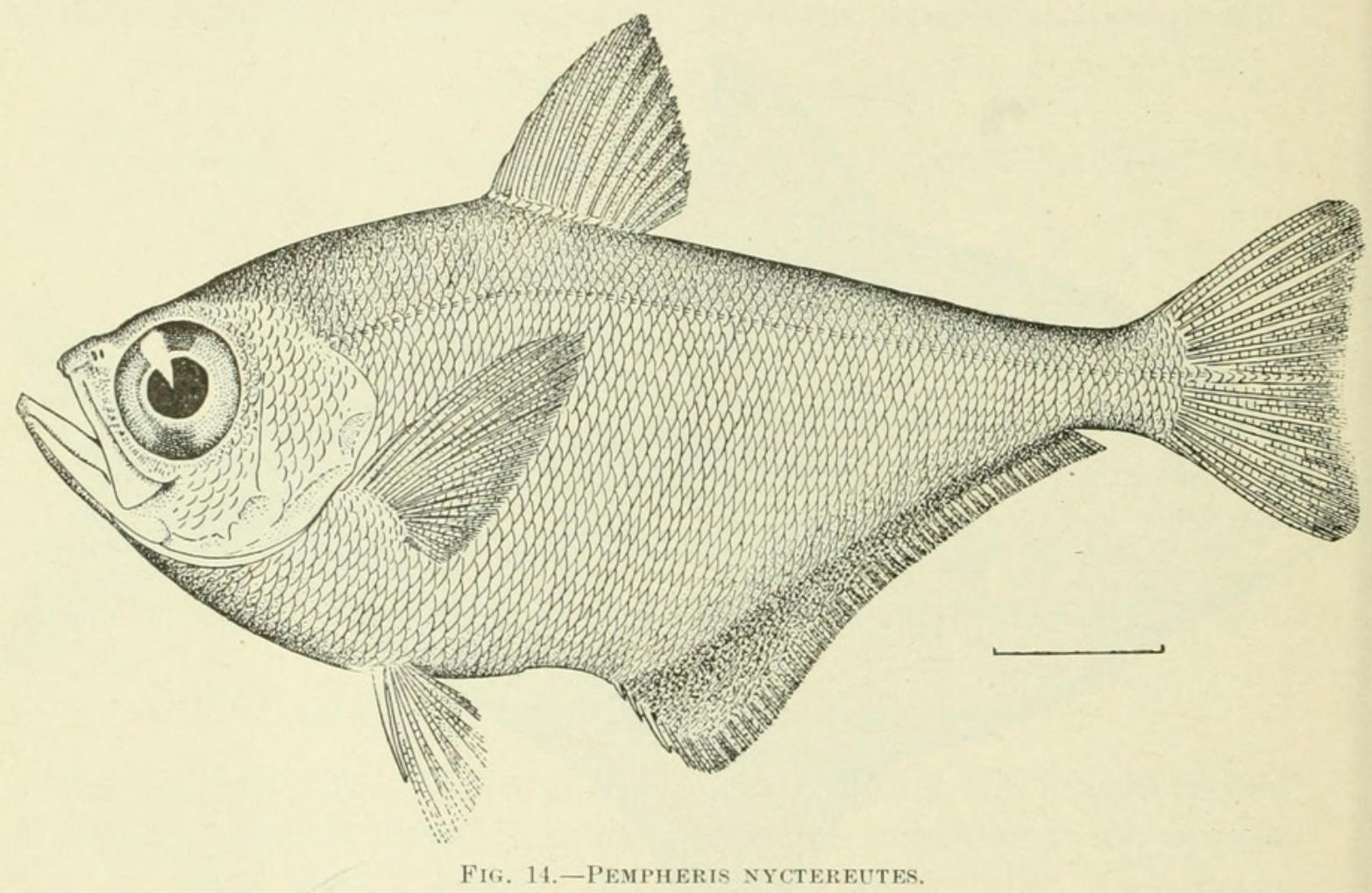

General color in alcohol, olivaceous brown; pectoral and ventrals pale; base of anal dusky brown; throat and under parts of head rusty brown.

Type.-No. 286, a specimen 8 inches long from Hokoto, Formosa, returned to the Imperial University.

\section{Family KUHLIID A.}

93. KUHLIA MARGINATA (Cuvier and Valenciennes).

One specimen, No. 319, from Kotosho, agreeing fairly with Boulenger's description.

Family SERRANID E.

94. PSAMMOPERCA WAIGENSIS (Cuvier and Valenciennes).

One fine specimen, No. 340, from Formosa, F. I. 
95. LATEOLABRAX JAPONICUS (Cuvier and Valenciennes).

One specimen, No. x z, from Formosa, F. I., and one specimen from Keerun.

96. EPINEPHELUS TAUVINA (Forskal).

(Serranus salmoides Day.)

Three specimens from Keerun, agreeing with Boulenger's description. Other specimens from Formosa are in the British Museum. One specimen, No. 376, with faint spots and with a broad black streak above maxillary.

\section{EPINEPHELUS MERRA Bloch.}

One specimen from Keerun. It belongs to the typical variety merra in Boulenger's Catalogue (I, p. 242).

98. EPINEPHELUS FUSCOGUTTATUS (Forskål).

One specimen, No. 3 x, from Formosa, F. I.

99. EPINEPHELUS EPISTICTUS (Schlegel).

One specimen, No. 280, from Giran, identical with one taken by us at Nagasaki. This species is near to $E$. latifasciatus, but is marked by spots only, not bands or stripes. A series of round blackish spots runs from the eye to the base of caudal. The spines on angle of preopercle are well developed.

One large specimen, No. x 7, from Formosa, F. I. Back sparsely covered with small round dark spots, no trace of dark lines; otherwise very near to Epinephelus latifasciatus, of which it may prove a color variation.

ıоo. EPINEPHELUS CHLOROSTIGMA (Cuvier and Valenciennes).

One specimen, No. 345, from Formosa, F. I. The spots are less numerous than are shown in the figures of Day and Bleeker, but the general characters agree with Boulenger's description.

One large specimen, No. 363, Formosa, F. I., corresponding to Day's figure of Serranus areolatus.

ror. EPINEPHELUS DIACANTHUS (Cuvier and Valenciennes).

One small specimen, the dark cross-bands scarcely traceable; a dark streak above maxillary.

A fine specimen, No. 374, from Formosa, F. I. Angle of opercle with two rather strong spines.

One small specimen, No. 355, Formosa, F. I., referred with doubt to this species. There are no dark cross-bands; body with darker spots, which form reticulations, some of them more or less longitudinal; fins unspotted, darker near the edge; a dark streak above maxillary. 
I02. EPINEPHELUS HCETI (Bleeker).

One specimen, No. 4 x, from Formosa, F. I. Head and body closely dotted with darker; caudal and anal broadly edged with black; ventrals chiefly black; dorsal with a brownish edge; pectoral plain yellow.

It is possible that Boulenger is correct in referring this species to the synonymy of Epinephelus flavocæmuleus (Lacépède), a species having the body plain blue or purple, the fins bright yellow.

I03. PROMICROPS LANCEOLATA (Bloch).

(Phrynotitan gigas Günther.)

One young example, No. 5 x, from Formosa, F. I.

Family LUTIANID E.

I04. GLAUCOSOMA BURGERI Richardson.

One large specimen, No. 364, 17 inches long, from Keerun, Formosa. Inside of mouth black; peritoneum black. This species seems

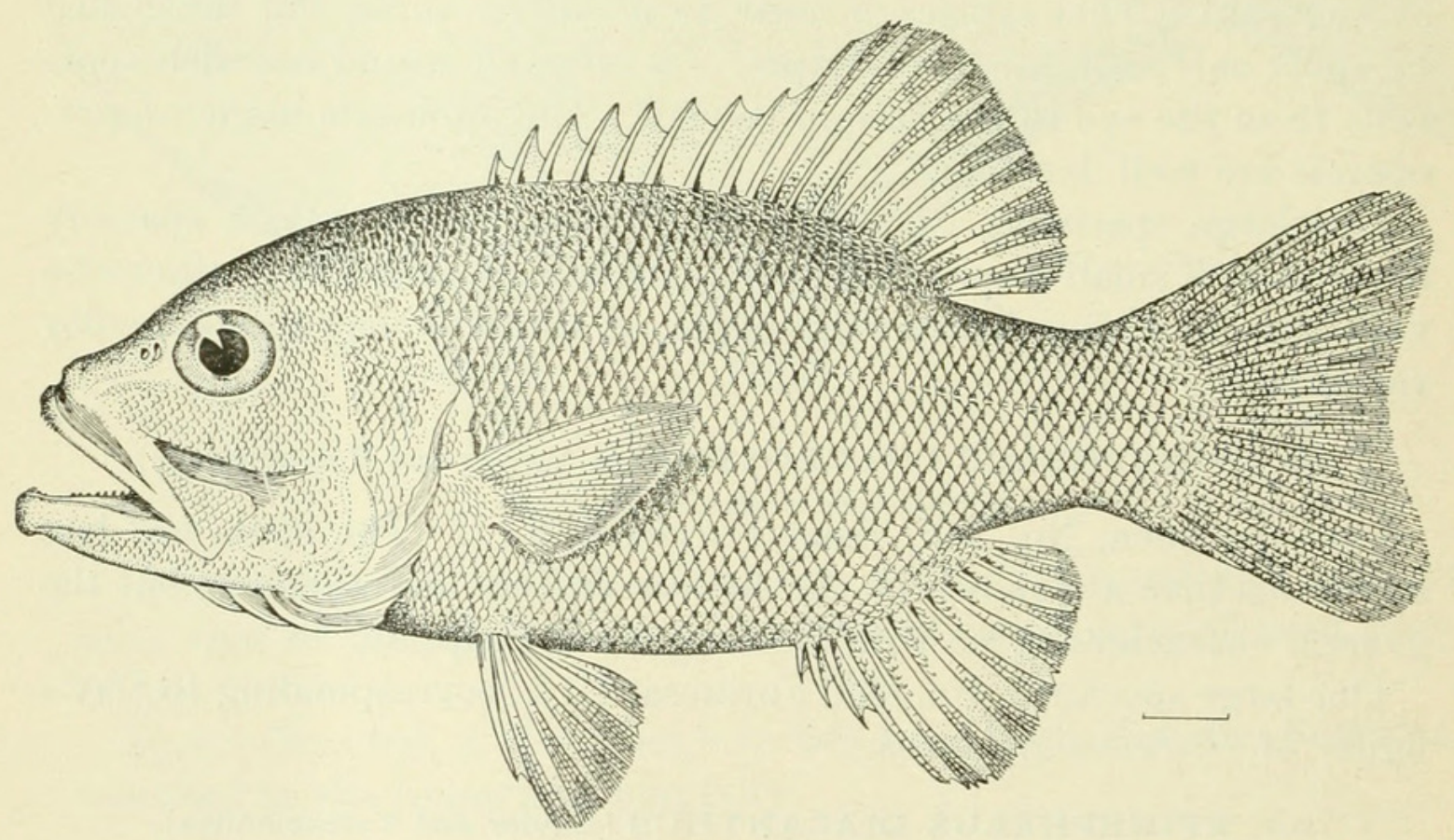

Fig. 15.-GLAUCOSOMA BURGERI.

distinct from Glaucosoma hebraicum Richardson. The genus belongs apparently to the Lutianidx, although the extension of the lateral line on the caudal fin suggests relationship to Lates and Psammoperca. The caudal fin is very slightly lunulate.

Head 2.75; depth 2.4; eye 3.8 ; snout 3.8 ; maxillary 1.65 ; mandible 1.6; interorbital 5; preorbital 7.3; D. VIII, 12; longest dorsal spine 3.5 , ray 1.9 ; A. III, 10 ; longest anal spine 4 , ray 2 ; ventral 2 ; pecto- 
ral 1.9; scales 12-52-20. Body rather short and deep, compressed; caudal peduncle compressed and deep, its least width 1.65 in eye, its least depth 2.5 in head; back gently and regularly arched from snout to caudal peduncle, somewhat depressed in front of eyes; head large and deep; mouth very large, somewhat oblique, jaws subequal; maxillary very broad at tip, scarcely slipping under preorbital; teeth in a strong villiform band on upper jaw composed of two rows, the outer in front canine-like; those of lower jaw in one series, except in front, where they are somewhat irregular; a large patch of villiform teeth on tongue and hyoid bone; a narrow $V$-shaped patch on vomer, apparently none on palatines; eye very large, rather high; nostrils close together, the posterior the larger. Scales moderate, weakly ctenoid, covering entire head, body and bases of dorsal, caudal and anal; maxillary densely scaled; base of pectoral scaled; preopercle at the angle with blunt coarse teeth. Fins moderate; dorsal spines rather short but strong, the soft part of dorsal somewhat elevated; anal similar to soft dorsal, the third spine considerably longest; caudal moderate, shallowly lunate, the lobes rounded; pectoral short and broad; ventrals scarcely reaching vent.

Color in alcohol, rusty silvery; head darker, somewhat purplish; edges of scales on side darkish, the bases brassy; dorsal, anal and caudal dusky; pectoral and ventral pale; a large brownish blotch on membrane below preorbital.

\section{LUTIANUS FULVIFLAMMA Forskål.}

(?Lutianus hoteen Richardson.)

A single specimen, badly faded, No. 332, from Keerun. It is identical with another received from Okinawa, and probably belongs to Lutianus hoteen, which Günther identifies with $L$. fuscescens from Celebes. In its dull olive coloration it approaches L. hoteen rather than L. fulviflamma Richardson, with which it agrees in the indistinctly notched preopercle.

It is not unlikely, however, that this is identical with the species figured by Dr. Day as the typical Lutianus fulviflamma as distinct from the golden-streaked Lutianus russelli.

Two specimens from Keerun. One large specimen, No. 344, from Formosa, F. I.

ro6. LUTIANUS ANNULARIS (Cuvier and Valenciennes).

One specimen, No. 291, from Formosa, F. I. Black blotch on caudal peduncle above very distinct, bordered before and behind by white; faint dark streaks along the rows of scales, those above oblique, those below horizontal, no trace of streak from first dorsal spine to eye. D. XI, 13 ; A. III, 8; scales 53. 
I07. LUTIANUS ARGENTIMACULATUS (Forskâl).

(Mesoprion gembra Günther.)

One specimen from Keerun. This species has much in common with Lutianus argentiventris and other American species. The parietal crest extends nearly to the point of junction of the supraoccipital crest and orbital rim, indicating that the genus Neomænis will be found untenable.

\section{ro8. LUTIANUS VITTA (Cuvier and Valenciennes).}

One specimen from Keerun.

Iog. PLATYINIUS SPARUS (Schlegel).

(Mesoprion sparus Schlegel.)

Head 3 ; depth 2.9; eye 3.2 ; snout 3.5 ; maxillary 2.25; mandible 1.9 ; interorbital 4 ; preorbital 6.25 ; D. X, 11; longest dorsal spine 2.75 in head; ray 2.75 ; A. III, 8 ; pectoral 1.25 ; ventral 1.7 ; scales

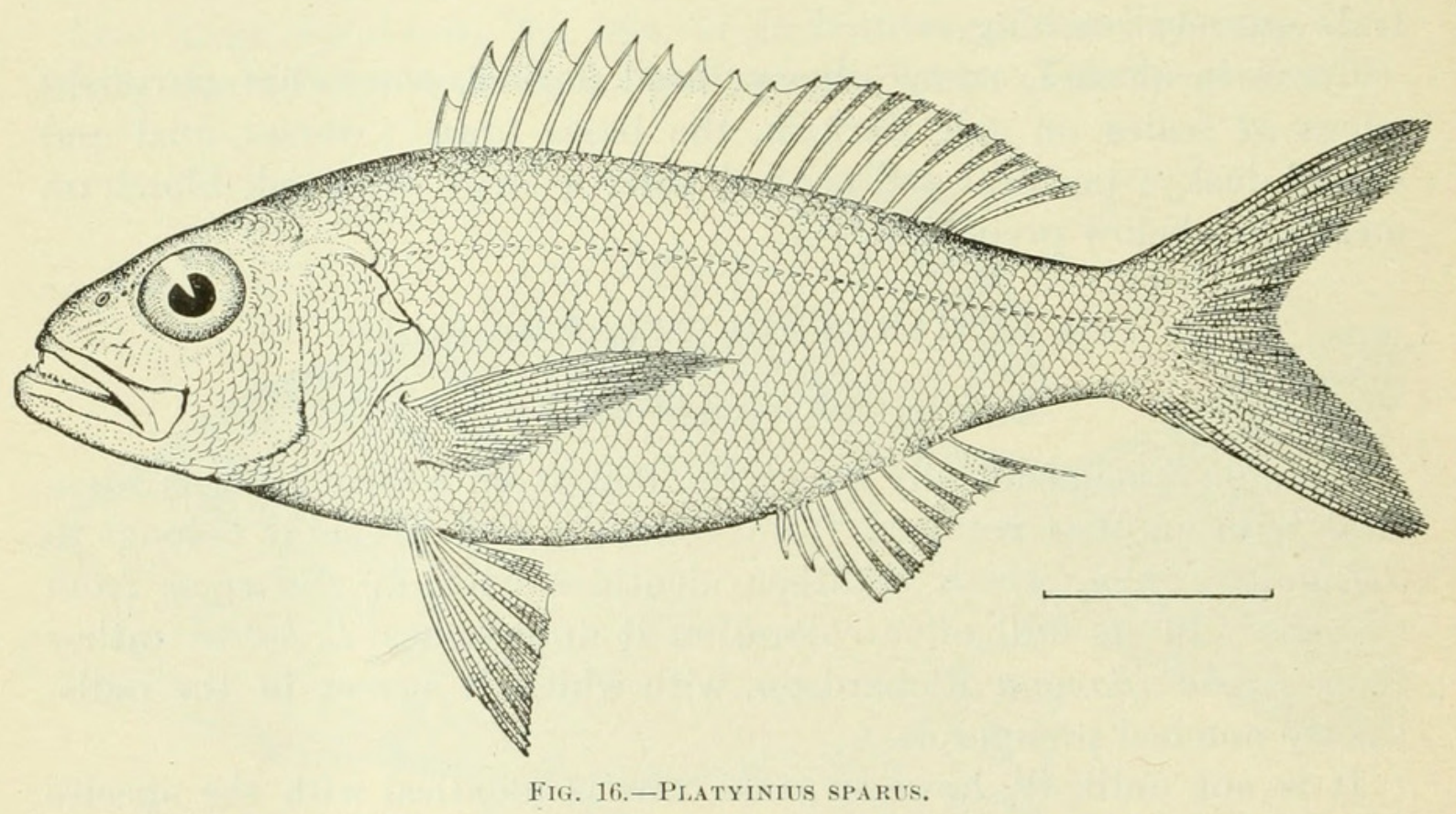

10-50-15. Body rather short, deep and compressed; dorsal and ventral outlines gently arched, occipital region slightly depressed; head large; mouth large, somewhat oblique, the lower jaw slightly the longer; maxillary broad, slipping for its entire length under the broad preorbital; eye large; nostrils very small; preopercle strongly serrate at angle. Scales small, nearly cycloid; cheek and opercle scaled, caudal fin scaled at base. Fins moderate, last ray of anal considerably produced.

One specimen, No. 367, 6.25 inches long, from Formosa, F. I. No scales at base of dorsal or anal fins; band of scales at the temples separated from those behind it; scales above lateral line in series 
parallel with lateral line; two strong canine teeth in front of each jaw, besides smaller lateral canines; teeth on vomer in a small V-shaped patch; no teeth on tongue; last ray of dorsal and anal produced; caudal deeply forked; gillrakers long, rather few in number, about 12 below angle; 6 rows of scales on cheek; preopercle scarcely notched, with fine long cirri; preorbital not so broad as eye.

Color, apparently bright red, now faded to silvery; cheeks bright silvery.

Platyinius spams has the skull of Etelis and Aprion, the compressed form of Platyinius, and the strong canines of Lutianus. Its nearest ally is doubtless Platyinius macrophthalmus, but it should be placed in a genus distinct from Aprion, characterized by the robust anterior canines.

\section{IIO. DENTEX HYPSELOSOMUS Bleeker.}

Head 2.75; depth 2.2; eye 3.8; snout 2.4; maxillary 2.6; mandible 2.5; interorbital 3.75; preorbital 3.75; D. XII, 10; longest dorsal

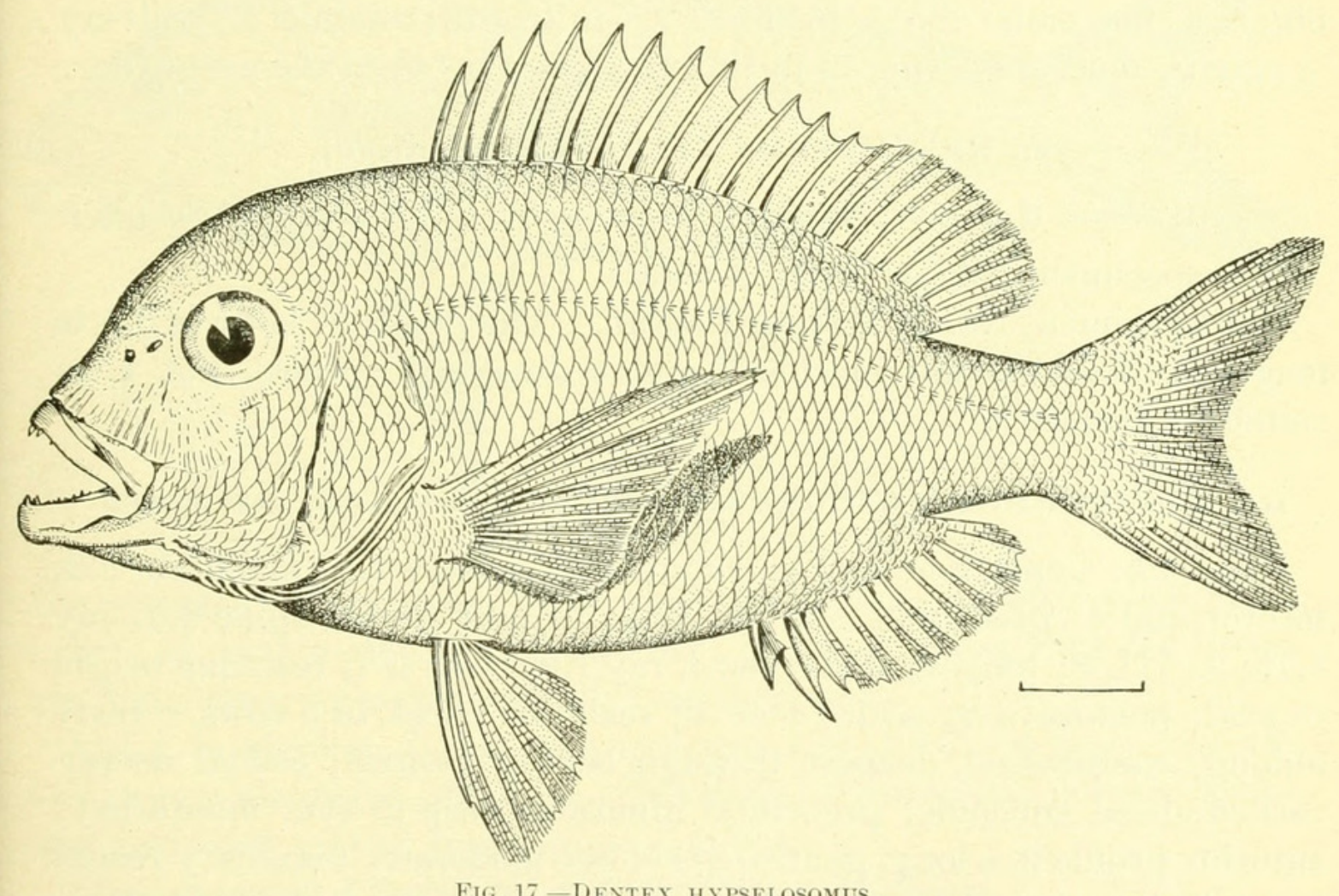

spine 2.5 ; ray 3.2 ; A. III, 8; longest anal spine 3 ; ray 3.2 ; ventrals 1.8; pectoral 1.2; scales 6-50-13. Body short, deep, and compressed, back considerably elevated and trenchant; the anterior profile concave in front of eyes and with a hump above; caudal peduncle moderately compressed, its least width 2 in eye, its least depth slightly greater than eye; head large and deep, mouth large, somewhat oblique, the jaws equal; maxillary heavy, slipping for most its length under the broad, thin preorbital; premaxillaries considerably protractile; teeth 
in jaws in an irregular sparse row, broadened into a patch anteriorly; tip of each jaw with 4 large, stout, recurved canines, behind which are the smaller, blunter teeth; no teeth on vomer, palatines, or tongue; eye large, rather high, entirely above upper lip; nostrils remote, the anterior small and round, the posterior larger and ovoid; preorbital very deep; edge of preopercle crenulate; opercle ending in a broad, flat point. Scales large, cycloid, firm, the exposed part much deeper than long; forehead, snout, and preorbital naked; posterior part of cheek and opercles with large scales; nape with smaller scales; a few scales on base of pectoral, and many fine scales on caudal. Fins moderate, the dorsal and anal each folding down into a scaly sheath at base; dorsal spines rather long and slender; anal spines heteracanthous, the second much broader than the others; ventrals not reaching vent; pectoral longer, reaching origin of anal.

No. xx, a specimen 11 inches long, from Formosa, and No. 366 from Formosa.

Forward very gibbous, with a slight concavity above the projecting snout; canines very strong; lateral teeth small, two-rowed, slightly bluntish, not molar-like. Pectoral 3.3 in length; canines $\frac{4}{4}$. Silvery in spirits, doubtless crimson in life, the space between the eyes paler.

\section{NEMIPTERUS VIRGATUS (Houttuyn).}

(Synagris sinensis (Lacépède) Günther; Dentex setigerus Cuvier and Valenciennes.)

One specimen, No. ix, from Formosa, F. I.

One specimen, No. 333, from Keerun. The depth of body is 3.5 in length (without caudal) in this common Japanese species, not 4 , as stated by Günther.

I12. NEMIPTERUS MATSUBAR $Æ$ Jordan and Evermann, new species.

Head 3.5; depth 3.5 ; eye 4; snout 3 ; maxillary 2.5; mandible 2.2; interorbital 6 ; preorbital 4.2 ; D. X, 9; longest dorsal spine 2.5 ; ray 1.75 ; A. III, 8; longest anal spine 3 , ray 1.9 ; ventral 1 , reaching origin of anal; pectoral 1.2; scales 4-48-9; scales on cheek in 3 rows. Body oblong, compressed, deepest through base of ventral; caudal deeply forked; head subconic; preorbital almost as deep as eye; mouth low, anterior profile in a long, gentle curve; eye moderate; maxillary reaching anterior edge of pupil; mouth moderate, horizontal; no teeth on vomer, palatines, or tongue, a single row of small cardiform teeth on sides of each jaw, in lower jaw this row widens into a band of villiform teeth, anteriorly, those in front slightly larger; lower jaw without canines; front of upper jaw with about 8 large, curved canine teeth; dorsal outline a straight line to base of caudal; soft dorsal slightly higher than spinous portion; first anal spine shortest, fin gradually lengthening to last ray; ventral and pectoral long and narrow; no filaments on the fins. 
Type.-No. 5071, specimen 10.6 inches long, from Giran, Formosa, returned to the Imperial University of Tokyo.

Head 2.5 (2.6 without flaps); depth 3.2 ; eye 5 ; snout 4.5 ; maxillary 2 ; mandible 1.7; interorbital 7.75; suborbital 12; D. XI, 13; A. III, 8; scales 22-110-40. Body short and compressed; head large, pointed; mouth very large, oblique, the lower jaw slightly projecting; maxillary long, reaching posterior edge of orbit; teeth strong, canine-like in jaws, the band broadening in front where the outer teeth are enlarged; patch of teeth on vomer and palatines, none on tongue; eye rather large; preopercle serrate, with 3 strong spines at the angle; opercle with 3 flat spines, the middle one strongest; nostrils small, in front of dorsal third of eye; interorbital narrow; caudal peduncle much compressed, its least depth 3.75 in head, with flap. Scales very small, covering body and entire head; lateral line slightly arched above

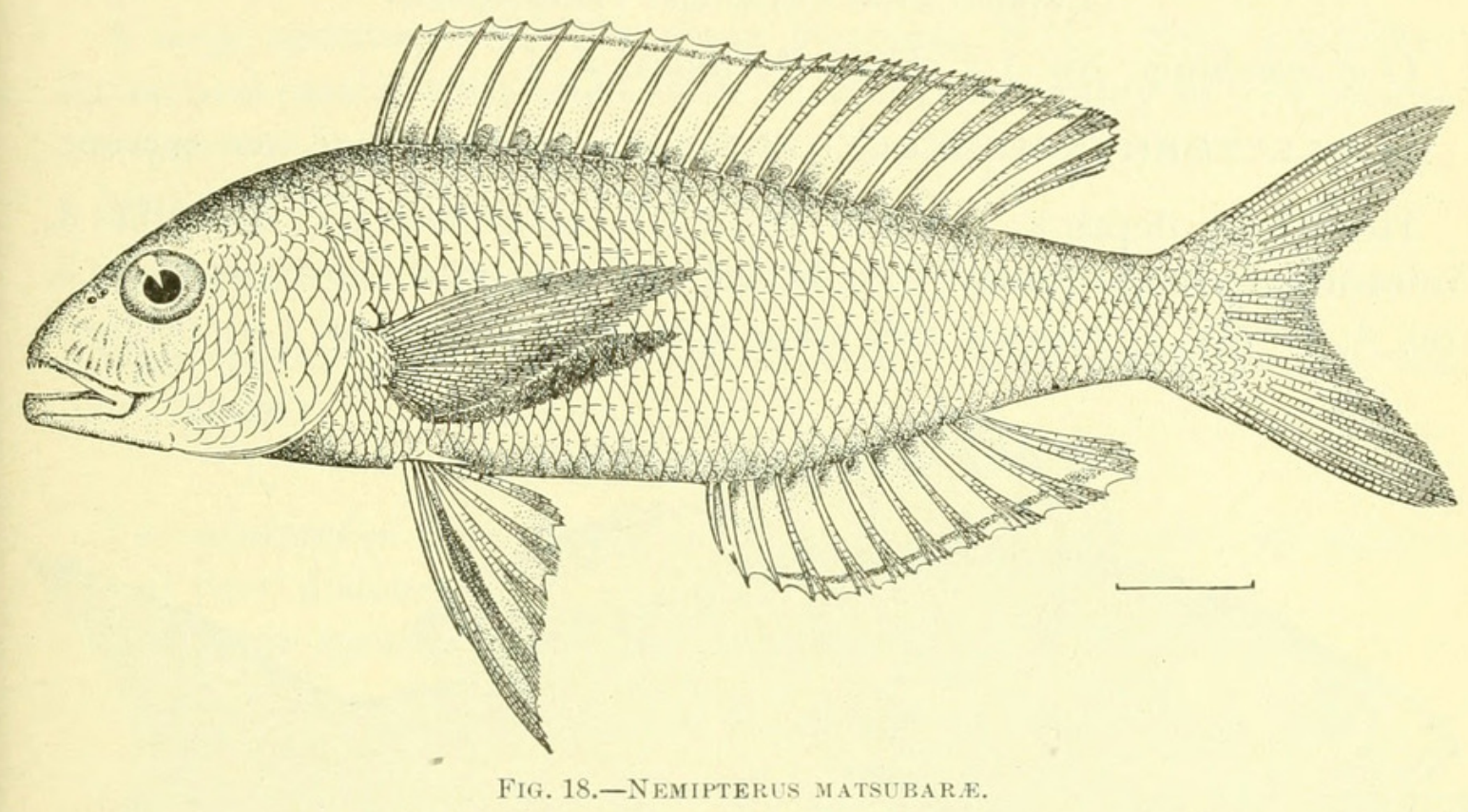

the pectoral. Fins rather high; origin of dorsal over opercular spines; origin of anal under first dorsal ray; pectoral rather long and broad, reaching vent; ventrals scarcely reaching vent.

Color in alcohol, light brown; upper two-thirds of body, opercle, and nape with sparse, small roundish dark brown spots; dorsal, caudal, and anal with similar spots, fewest on anal.

One specimen 8 inches long, from Giran, Formosa.

General color in alcohol, pale dusky gray with silvery reflections, and some slight indications of dark in narrow lines on edge of scales along lateral line, and over body posterior to front of anal; dorsal and anal dark at base, this dark being in cresent spots as large as pupil on anterior base of membrane, rest of fin pale; caudal and pectoral pale; ventrals pale, except the third ray, which is yellow; this yellow extends on to the posterior base of the first and second rays; dorsal with a light yellow edge, anal with a yellow median stripe and a yellow edge. 


\section{Family HAMULIDA.}

I13. THERAPON THERAPS (Cuvier and Valenciennes).

One specimen from Keerun.

II4. THERAPON CANCELLATUS (Cuvier and Valenciennes).

One specimen from Kotosho, agreeing fairly with Bleeker's figure.

\section{II5. THERAPON QUADRILINEATUS (Bloch).}

One specimen, No. 284, from Giran, agreeing with the account given by Dr. Günther. One specimen from Keerun.

II6. THERAPON JARBUA (Forskål).

(Therapon servus Cuvier and Valenciennes.)

One specimen, No. 7 x, from Formosa, F. I.

II7. PLECTORHYNCHUS OCYURUS Jordan and Evermann, new species.

Head 3.75 ; depth 3 ; eye 3.5 ; snout 3.5 ; maxillary 3.2 ; mandible 3 ; interorbital 4; preorbital 9.5; D. XIV, 18; longest dorsal spine 2.3, ray 3 ; A. III, 8; longest anal spine 2.5 , ray 2.5 ; ventral 1.5 ; pectoral

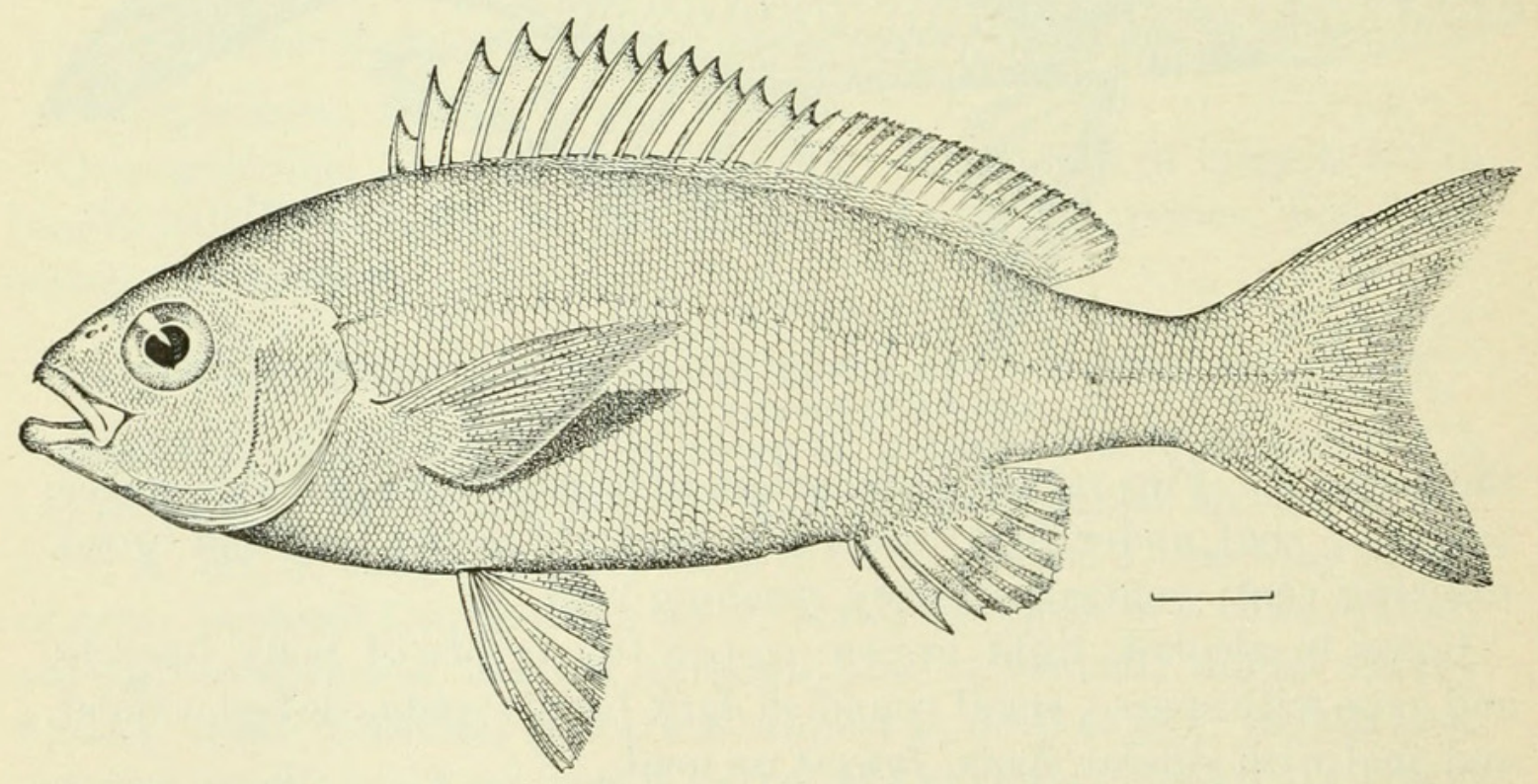

Fig, 19.-PLECTORHYNCHUS OCYURUS.

1.2; scales 19-115-21. Body rather long and compressed, the dorsal and ventral outlines about equally arched; nape rather trenchant; head moderate, pointed, jaws equal; maxiliary broad at tip, slipping under preorbital for its entire length; teeth on jaws in a moderately broad band, the outer in front enlarged and canine-like, especially in upper jaw; no teeth on vomer, palatines, or tongue; eye very large, on level of upper lip; nostrils small, close together, oval, on level of upper edge of orbit; preopercle with numerous rather strong, slender 
teeth. Scales small, ctenoid, densely covering entire head and body and extending considerably upon caudal fin; a scaly sheath at base of anal and dorsal; lateral line nearly straight, an occasional scale without a pore. Fins rather high; the dorsal spines long, sharp, and slender; second anal spine strong; caudal somewhat lunate; the pectoral long and somewhat falcate, reaching tips of ventrals.

Color in alcohol, yellowish-olive, somewhat rusty on head; membrane of spinous dorsal edged with black; a faint dark line through middle of soft dorsal; anal dusky, pale at tip.

Type.-No. 347, a specimen 12.5 inches long, from Formosa, returned to the Imperial Fisheries Institute.

\section{II8. PLECTORHYNCHUS RADJABAN (Lacépède).}

(Diagramma punctatum Cuvier and Valenciennes.)

A large specimen, No. 372, from Formosa, F. I. Body unspotted; dorsal and caudal with black spots, thus corresponding to Diagramma cinerascens Cuvier and Valenciennes. D. X, 21.

One specimen, No. 346, from Formosa, F. I.

ir. PLECTORHYNCHUS PCECILOPTERUS (Cuvier and Valenciennes).

One specimen, No. 270, from Keerun. One specimen, No. 305. from Giran.

I20. POMADASIS HASTA (Bloch).

Two specimens from Keerun. Spots on back obscure; on spinous dorsal very distinct.

One large specimen, No. 353, from Formosa, F. I.

\section{I2I. POMADASIS MACULATUS (Bloch).}

One specimen from Keerun. The snout a little more blunt than in Day's figure.

\section{SCOLOPSIS VOSMERI (Bloch).}

(Scolopsis japonicus Bloch; Scolopsis torquatus Cuvier and Valenciennes.)

One specimen, No. 331, from Keerun. White nuchal band very conspicuous; each scale with a dark blotch surrounded by pearly blue. The name vosmeri (1790) has priority over that of auratus (1797). According to Dr. Day, Scolopsis torquatus, which our specimen represents, is the young of S. vosmeri.

123. SCOLOPSIS MONOGRAMMA (Kuhl and Van Hasselt).

One specimen from Giran, No. 287, agreeing with the account given by Cuvier and Valenciennes. A rather broad dark band extends below the lateral line from the head to base of caudal, broader mesially and bordered above and below by pale.

One specimen, No. 306, from Keerun. 
I24. CÆSIO CHRYSOZONA (Kuhl and Van Hasselt).

One specimen from Keerun.

I25. CÆSIO TILE Cuvier and Valenciennes.

A small specimen in poor condition from Keerun, the dusky lateral band almost obliterated, probably belongs to this species. Axillary spot distinct; each caudal lobe with a broad dusky lengthwise band; side of body apparently with a broad dark longitudinal band. D. X, 16 .

$$
\text { Family SPARIDA. }
$$

126. LETHRINUS LEUTJANUS (Bloch).

One large specimen, No. 334, from Formosa, F. I.

One specimen, No. 310, from Giran. The pearl-colored spots on the scales are still very distinct.

127. LETHRINUS RICHARDSONI Günther.

One specimen corresponding very closely to Richardson's figure. ${ }^{1}$ I28. PAGRUS MAJOR (Schlegel).

One large specimen, No. xII, from Formosa, F. I.

A large specimen, No. 373, from Formosa, F. I.

129. PAGRUS CARDINALIS (Schlegel).

One specimen, No. 13 x, from Formosa, F. I.

130. ARGYROPS LONGIFILIS (Cuvier and Valenciennes).

One specimen, No. 318, from Kotosho. This species seems to be distinct from Argyrops spinifera; the body is a little deeper depth 1.9), and the third, fourth, fifth, and sixth spines have fleshy-like filaments reaching almost to end of caudal. The genus Argyrops of Swainson differs from Pagrus in its filamentous dorsal, a character of doubtful value.

I31. SPARUS BERDA Forskàl.

One specimen, No. $10 \mathrm{x}$, from Formosa, F. I. It agrees with Chrysophrys datnia of Day in the anal spines and with C.berda in the width of the preorbital. It is not unlikely that Günther and Steindachner are right in referring all of these to one species.

I32. SPARUS LATUS Houttuyn.

(Chrysophrys aries Schlegel.)

One specimen, No. 5072, from Giran. 
in front of ventrals; second dorsal high, the free margin concave, anal similar to soft dorsal, the last ray more produced; caudal ray deeply lunate, the lobes much produced and falcate; pectoral moderate, somewhat falcate, four filamentous rays widely detached and nearly equal to head in length; ventrals short. Scales rather small, smooth, thin, and deciduous; lateral line extending upon lower lobe of caudal which is scaled at base.

Color in alcohol, silvery, the spinous dorsal and pectoral fins dark, anterior edge of second dorsal also dark; detached pectoral rays white.

Type.-No. 17 x, a specimen 10.75 inches long, from Formosa, F. I., returned to the Imperial Fisheries Institute.

\section{Family GERRID A.}

\section{XYST ÆMA FILAMENTOSUM (Cuvier and Valenciennes).}

One specimen, No. 323, from Kotosho.

Dorsal filament broken. Faint, roundish, brownish spots present as shown in Bleeker's figure, these arranged in vertical cross rows; obsolete dark spots at base of dorsal rays. Depth 2.4 in length; scales 46 .

One fine specimen, No. $40 \mathrm{x}$, from Formosa, F. I.

\section{Family POMACENTRID A.}

\section{GLYPHISODON SAXATILIS (Linnæus).}

Head 2.5 in length; depth 2; D. XIII, 13; A. II, 12; scales 5-30-12.

Dark bands 5, about as broad as the interspaces, the first from the nape to the axil forming a black spot on the pectoral; two below the spinous dorsal, the fourth under front of soft dorsal, the last under caudal peduncle; spinous dorsal dusky; soft dorsal and anal dusky at base and tip; caudal plain, without dark margin above or below.

This is Glyphisodon colestimus (the variety with plain caudal) of Günther and Bleeker, and corresponds fairly to Bleeker's fig. 5 in Pl. IX, in Bleeker's Atlas of the Pomacentridæ. But the true Glyphisodon colestinus has the caudal edged above and below with blackish. Whether this character is of distinctive value we have not the material to decide.

The names Chxtodon saxatilis and Chxtodon rotundus of Linnæus seem to belong to the present species. The American species, heretofore called Glyphisodon saxatilis, is a different species, having six black bands, the body deeper and the bands narrower. This may stand as Glyphisodon marginatus (Bloch). The Hawaiian species Glyphisodon abdominalis (Cuvier and Valenciennes), with deeper body and very narrow crossbands, is also different, although more like $G$. marginatus. It is not certain whether this species or $G$. calestimus is the original of Chxtodon saxatilis, or indeed that the two forms are really distinct, 
Body short, stout and compressed; anterior profile very steep, in a strong curve from tip of snout to origin of dorsal fin; head large; mouth large, the gape reaching middle of eye; jaws armed each with about four large, strong canines in front, with short, blunt, coalesced teeth on sides; three somewhat stronger close-set canines at base of upper jaw; eye moderate, high up; caudal peduncle deep and much compressed. Scales very large, thin, and adherent, those on cheek much reduced. Dorsal fin long, moderately high, and beginning over base of pectoral; anal beginning under twelfth dorsal spine, the last rays somewhat produced; caudal squarely truncate; pectoral broad, fan-shaped, the upper rays the longer; ventrals long and pointed, reaching vent, coterminous with the pectoral.

Color in alcohol, dirty olive-brown, scales of side and breast broadly edged with black or dark brown, irregular hair-like lines of dark over rest of scale; lateral line dark; base of pectoral dark, with a broad blue line through it; upper edge of pectoral with dark blotches; caudal peduncle with about 6 longitudinal series of oblong bright blue spots; fins all dusky and yellowish.

142. DUYM ERIA FLAGELLIFERA (Cuvier and Valenciennes).

(Ctenolabrus aurigaria and C. rubellio Richardson).

One specimen, from Keerun.

This species is probably identical with the Japanese species, Duymæria Alagellifera Cuvier and Valenciennes, of which Duymæria japonica Bleeker is a synonym. The equally common Japanese form, Duymæria spilogaster Bleeker, is the female of D. Alagellifera.

\section{ANAMPSES CARULEOPUNCTATUS (Rüppell).}

One fine specimen, No. 343, from Formosa, F. I.

144. HEMIPTERONOTUS VERRENS Jordan and Evermann, new species.

One specimen from Keerun, distinguished by the very long ventrals.

Head 3.5 ; depth 2.9 ; eye 4.3 ; snout 2.4 ; interorbital 2 in snout; D. II-VIII, 12; A. III, 12; scales 3-29-7. Body short, deep, and very greatly compressed; head very short, the anterior profile nearly vertical; body highest at base of pectoral, thence tapering evenly on dorsal and ventral profiles to caudal; nape trenchant; eye high up; mouth small and low; teeth on jaws in a single close-set row, two outwardly directed strong canines in front in each jaw. Scales very thin; cheek with smaller scales; rest of head naked; lateral line running high, until near end of soft dorsal, where it drops 3 scales. Dorsal fin beginning on nape above posterior edge of orbit, the first 2 spines 
detached and somewhat longer; anal beginning under first soft dorsal ray; caudal somewhat pointed or rounded; pectoral long and slightly falcate; ventral with the outer ray produced, reaching past front of anal.

Color in alcohol, pale yellowish, somewhat rosy on opercle; posterior part of side with indications of indistinct longitudinal lines; doubtless red in life.

Type.-A specimen t.5 inches long, No. 7134, Stanford University Museum.

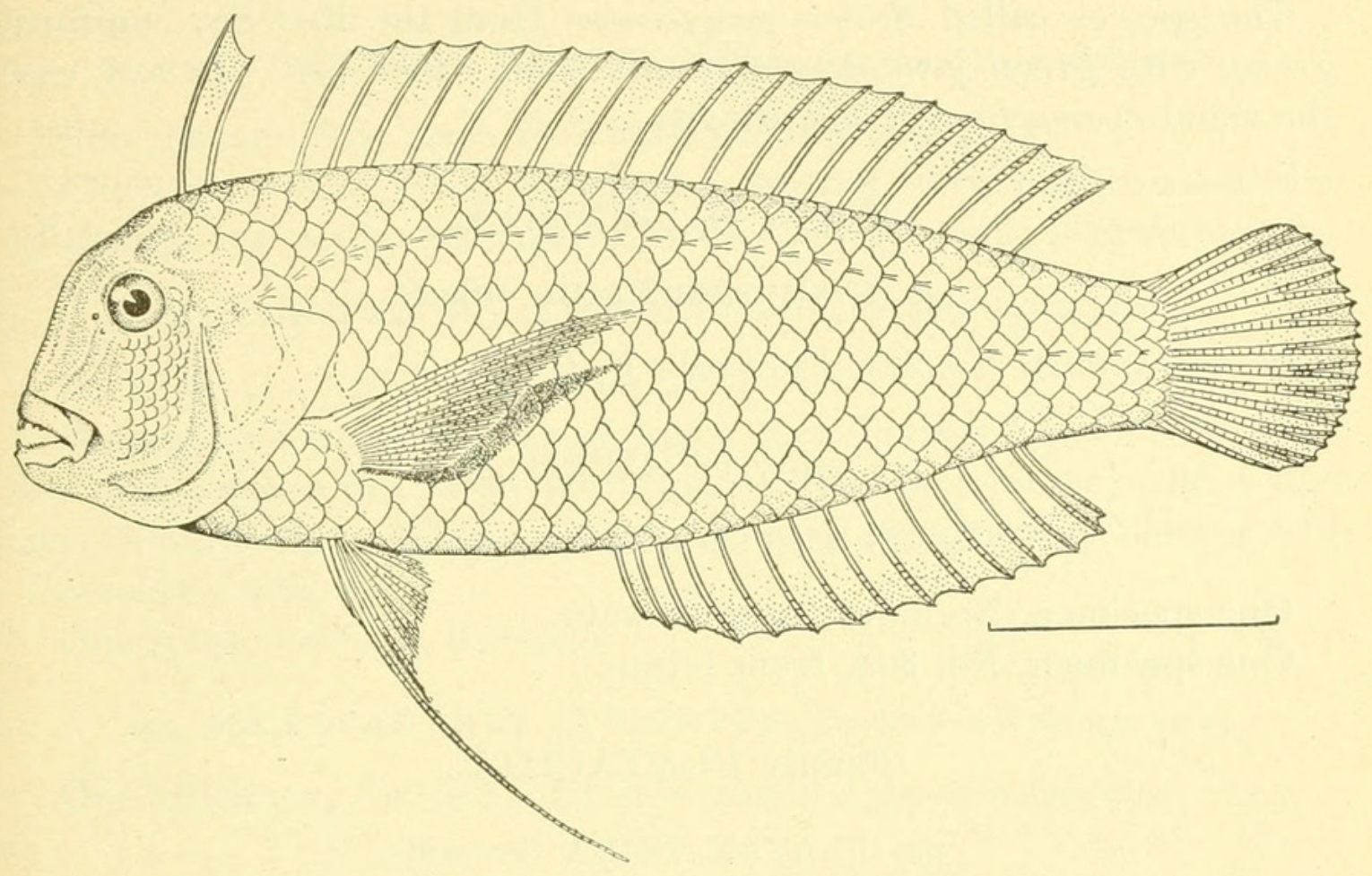

Fig. 22.-HEMIPTERoNotus VERRENS.

145. GUNTHERIA CENTIQUADRA (Lacépède).

(Julis hortulanus Cuvier and Valenciennes.)

Coloration as described by Dr. Günther, except that no dark spots appear at base of caudal above; caudal and anal nearly plain. Canines $\frac{2}{2}$, the pair of small teeth next them somewhat enlarged; posterior canine inconspicuous, much smaller than figured in $G$. centiquadra. It is probably, however, not a distinct species. One specimen from Kotosho.

The genus Guntheria (including Hemitautoga) may be retained for those species of Halichores which have the upper part of the cheek covered with small scales, the cheek in Halichores being naked.

146. CHEILO INERMIS (Forskâl).

One specimen, No. 11434, from Formosa, F.'I. 


\section{Family SCARIDA. \\ 147. SCARUS LACERTA (Cuvier and Valenciennes).}

(Scarus xruginosus Bleeker, Günther, Day; probably not of Cuvier and Valenciennes.)

A fine specimen, No. 37 x, Formosa, F. I.

No posterior canine; upper lip covering more than half of upper jaw; two rows of scales on cheek, with one or two below on opercular limb; caudal short, lunate; three pale streaks on side of belly; dorsal edged with dusky; caudal rather dark, the color otherwise lost.

The species called Scarus xruginosus from the Red Sea, uniform green, with green jaws, is apparently some other fish. In any case the name Scarus lacerta has priority.

Family ILARCHID A.

148. ILARCHES ORBIS (Bloch).

One specimen, No. 351, Formosa, F. I.

Family EPHIPPID A.

149. EPHIPPUS ARGUS ${ }^{1}$ (Gmelin).

One specimen, No. 5073, from Suwata.

One specimen, No. 309, from Giran.

\section{Family PLATACID A.}

I50. PLATAX TEIRA (Forskål).

One specimen, No. 298, from Hokoto, agreeing with a Japanese specimen from the coast of Rikuzen.

D. V, 33 ; scales 60 .

One specimen, No. 341, Formosa, F. I.

Family CH ATODONTID E.

I5I. CHÆTODON PRÆTEXTATUS Cantor.

(? Chrtodon reticulatus Cuvier and Valenciennes.)

(Chrtodon collaris Bleeker; not of Bloch.)

Two specimens, Nos. $12 \mathrm{x}$ and 296, Formosa, F. I.

A specimen, No. 365, from Formosa, F. I.

These differ from a Japanese specimen (from Satsuma) of Chætodon collaris Bloch (= Chxtodon aureus Schlegel $=$ Chxtodon auripes Jordan and Snyder), in not having any of the dark streaks branched or forked

${ }^{1}$ This species is the original type of Cuvier's genus Ephippus. Ephippus should replace Scatophagus and Cacodoxus. 
behind, as is the case in the Japanese specimen and as figured by Schlegel (Chxtodon aureus). In the Japanese species the white band before the eye ceases at the level of the eyes, while in the Formosa species it extends above it. The Formosan specimens belong to Chrtodon collaris Bleeker, not Bloch, but we are not quite sure of their identity with $C$. reticulatus.

\section{CHETODON FASCIATUS Forskål.}

(Chrtodon lunula Lacépède.)

One specimen from Kotosho identical with others from Honolulu.

I53. CHÆTODON LINEOLATUS Cuvier and Valenciennes.

Nos. 299 and 301, from Hokoto (Pescadores Islands).

Chrtodon semilarvatus, described as having 12 vertical cross-streaks of orange, can not be this species, as this one has about 16 cross-streaks.

154. CHATODON CITRINELLUS Cuvier and Valenciennes.

D. XIV, 21; A. III, 16; scales 36 .

Dark spots along the rows of scales very distinct, as is also the yel low stripe above the broad black edge of the anal; dorsal with a very narrow dark edge. This species is wrongly identified by Bleeker with Chxtodon miliaris.

One specimen from Kotosho.

I55. MICROCANTHUS STRIGATUS (Cuvier and Valenciennes).

One specimen, No. 311, of this common Japanese species.

\section{Family ACANTHURIDA.}

\section{TEUTHIS TRIOSTEGUS (Linnæus).}

One specimen, No. 326, from Kotosho.

Belly abruptly white, below a wavy bounding line; two black spots at base of caudal. one at upper, the other at lower edge; a black bar below eye; four black bars below dorsal fin; four black spots about base of pectoral; lips black.

This species, which is probably the original triostegus, differs from the species called by that name in Hawaii and on the off-shore islands of Mexico. The latter is Teuthis sandwichensis (Streets), its earlier synomymy, if any exists, being confused with that of $T$. triostegus.

157. TEUTHIS DUSSUMIERI (Cuvier and Valenciennes).

A large specimen, No. 335, Formosa, F. I.

D. IX, 26. Dark spots on eaudal very distinct; traces of narrow wavy blue stripes on head, and faint traces of the same on body; a pale area about eyes; fins obscurely marked. 
One specimen, No. 300, from Hokoto.

Allied to Teuthis argenteus (= matoides) and related species, but distinguished by the spotted caudal fin.

158. TEUTHIS BIPUNCTATUS (Günther).

(Acanthurus nigros Günther; not A. nigroris Cuvier and Valenciennes.)

Two specimens, No. 322, from Kotosho.

The synonymy of this species is rather uncertain. Our specimens are characterized by the plain dark-brown coloration, with ink-like spots in axil of dorsal and anal; lips black. Caudal deeply lunate, the upper lobe the longer. D. IX, 25; depth 2.17 in length.

I59. TEUTHIS OLIVACEUS Solander.

A fine specimen, 13 inches long, No. 362, from Formosa, F. I.

This species is apparently the original Teuthis olvacens, although different from the Polynesian species called by that name. D. IX, 24. Caudal lobes greatly produced. Orange band on shoulder extending to end of pectoral.

Head 4; depth 2.2; eye 4.75; snout 1.3; interorbital 2.75; D. IX, 24 ; longest dorsal spine 2.5 , ray 1.6 ; A. probably about III, 27 , the fin broken and hard to count accurately; ventrals 1.3; pectoral 1.2;

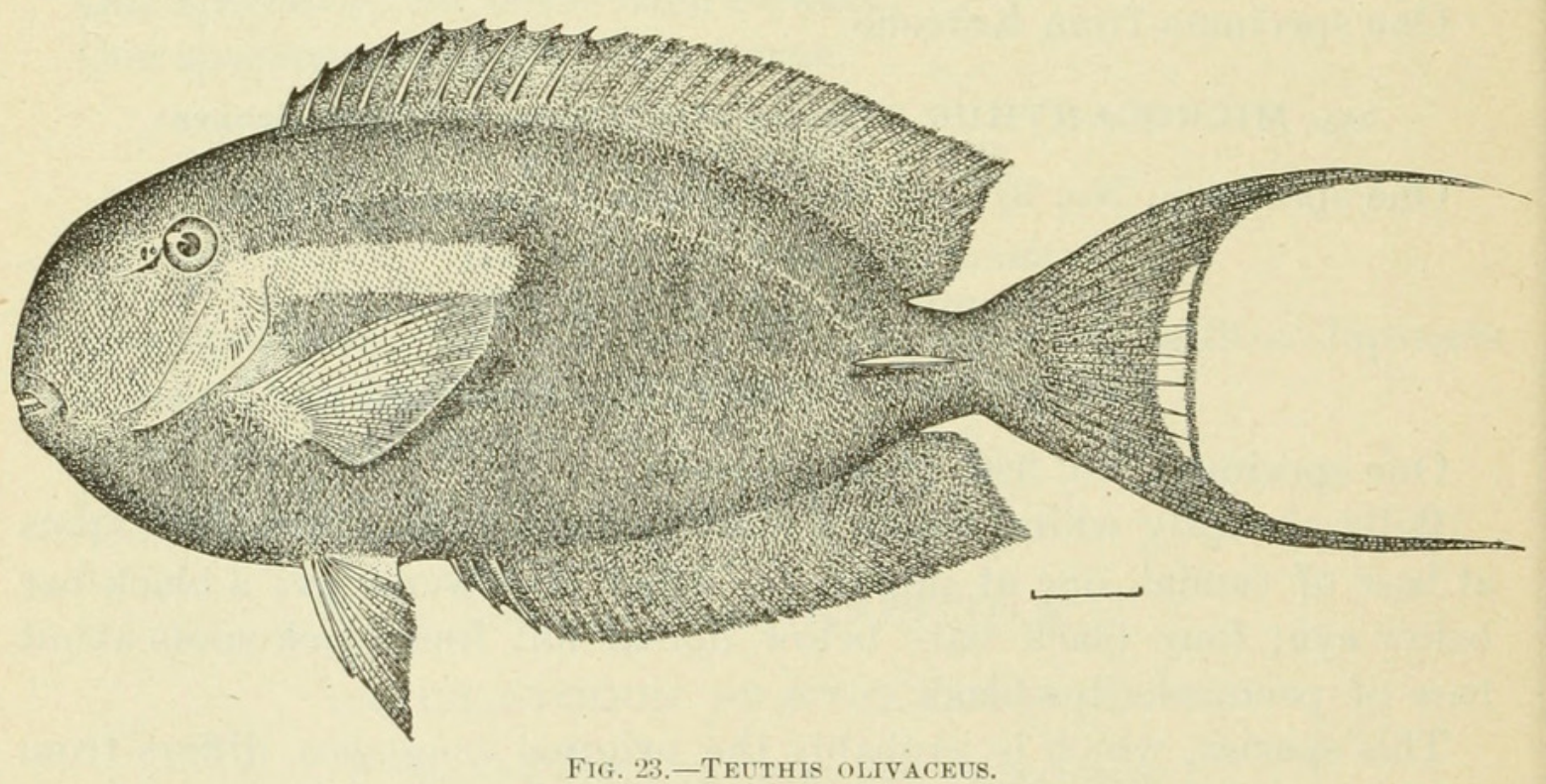

scales about 140. Body oblong, compressed; dorsal and ventral outlines similarly arched; profile of head strongly arched, the outline almost vertical anteriorly; head rather short, the snout blunt; mouth very small, jaws equal; teeth broad, flat incisors, the tips and sides strongly denticulate; preopercular margin very oblique; branchiostegal membranes forming a fold across chin; eye small; nostrils close together in front of eye, the anterior somewhat the larger; caudal spine strong, somewhat keeled. Scales very small, strongly ctenoid, 
densely covering entire body and head; a few scales on soft dorsal and anal; caudal fin densely scaled; dorsal fin beginning on nape just back of eye, the spines somewhat depressible in a groove, the last soft rays produced; anal similar to soft dorsal but the base longer; caudal lunate, the upper and lower lobes greatly produced; ventrals rather short, reaching origin of anal; pectoral short and broad, somewhat falcate.

Color in alcohol, dark brown, almost black; a long creamy white blotch on side from upper end of opercle to vertical at tip of pectoral, this bounded by jet black; fins all blue-black, except caudal which has a broad, subterminal, white bar on the middle rays, a narrow black border on tips of rays; pectoral black, the outer fifth yellowish white.

Family SIGANIDA.

r6o. SIGANUS VERMICULATUS (Kuhl and Van Hasselt).

One specimen, No. 5074, from Suwata.

Similar to Siganus vermiculatus, but with the body much more elongatt; depth 2.5 in length, without caudal. This difference is perhaps due to the immaturity of the specimen.

\section{I6r. SIGANUS FUSCESCENS (Houttuyn).}

(Siganus albopunctatus (Schlegel).)

One specimen, No. 290, from Formosa, F. I. It is covered with small rounded bluish white spots, as usual in Japanese examples.

Two large specimens from Keerun; one specimen, No. 14x, from Formosa, F. I.

Family MONACANTHIDE.

162. STEPHANOLEPIS SULCATUS (Hollard).

One small specimen, No. 276, from Keerun.

Depth about half length; dorsal spine 1.7 in head; anal rays 32. Body covered with fine longitudinal striæ, the raised keels of the rows of scales.

\section{Family TETRAODONTID Æ.}

163. SPHEROIDES OCELLATUS (Osbeck).

One specimen, No. 330, from Hokoto.

Dark blotches behind pectorals forming a bar across the back.

I64. SPHEROIDES SCELERATUS (Forster).

One specimen, No. 283, from Hokoto, agreeing with the description given by Günther (VIII, 276). The back is dark brown, covered with darker spots of various sizes; the sides very abruptly silvery. 


\section{Family DIODONTID A. \\ I65. DIODON HOLACANTHUS Linnæus.}

One specimen from Hokoto, No. 277, similar to Japanese examples.

$$
\text { Family SILLAGINID A. }
$$

r66. SILLAGO SIHAMA (Forskål).

One specimen, No. 292, from Formosa, F. I.

r67. SILLAGO ÆOLUS Jordan and Evermann, new species.

Head 3.4 ; depth 5.6; eye 3.6 ; snout 2.5; interorbital 5.5; D. XI-I, 19; A. II, 17; scales 5-76-8. Body long, slender, and compressed; anterior profile gently arched from tip of snout to origin of spinous dorsal; ventral outline nearly straight; head long, the snout pointed; mouth small, low, somewhat oblique, the lower jaw included; teeth in

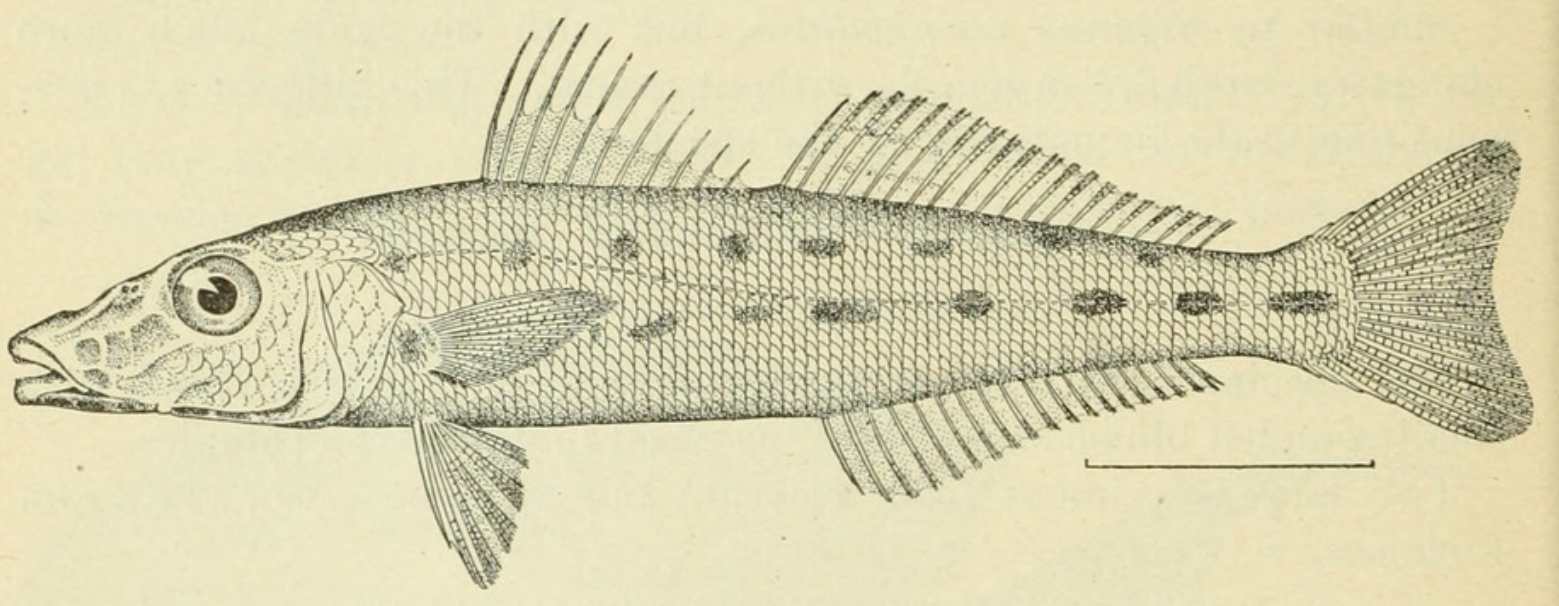

Fig. 24.-Sithatgo EOLUS.

broad villiform bands on each jaw and on vomer; head very rugose, the muciferous structure strongly marked; eye large, lateral; snout long and pointed; caudal peduncle moderate, compressed, its least depth a little more than one-half snout. Scales rather thin, somewhat irregular, weakly ctenoid; lateral line complete, slightly arched above the pectoral; nape scaled, head naked, except on cheek, where there are about two rows of large scales. Dorsal fins two, the first of long, slender spines, its origin above middle of pectoral; interspace between fins short; anal similar to soft dorsal, its origin somewhat more posterior; pectoral and ventrals moderate; caudal slightly forked.

Color in alcohol, pale straw-color; middle of side with two series of large, oblong, blackish blotches, about six or seven in each series; a plumbeous silvery band along middle of side below lateral line, most distinct posteriorly; fins all somewhat punctulate.

Type.-A specimen 5.25 inches long from Keerun, Formosa, No. 7135, Stanford University Museum. 
Family LATILIDA.

I68. LATILUS JAPONICUS (Houttuyn).

(Latilus sinensis (Lacépède); Latilus argentatus Cuvier and Valenciennes.)

One specimen, No. 30x, from. Formosa, F. I.; one specimen, No. 368, from Formosa, F. I.; one specimen, No. 5070, from Giran.

\section{Family PLATYCEPHALID E.}

i69. PLATYCEPHALUS INERMIS (Houttuyn).

(Platycephalus crocodilus Tilesius; Platycephalus guttatus Schlegel.)

One specimen from Keerun, apparently identical with others from Hiroshima.

I70. PLATYCEPHALUS INDICUS (Linnæus).

(Platycephalus insidintor Forskảl.)

One large specimen, No. 342, from Formosa, F. I. One large specimen, No. $31 \mathrm{x}=361$, from Formosa, F. I.

Family TRIGLID A.

I7i. LEPIDOTRIGLA ALATA (Houttuyn).

(Lepidotrigla bürgeri Schlegel.)

One fine specimen, No. 288, from Hokoto (Pescadore Islands).

\section{Family CEPHALACANTHID A. \\ 172. CEPHALACANTHUS JAPONICUS (Bleeker).}

One small example, No. 289, from Giran, apparently similar to the Japanese species, the proper name of which is still uncertain.

\section{Family GOBIID E.}

I73. ELEOTRIS FUSCA (Schneider).

One specimen, No. 5076, from Suwata. Scales about 55. Otherwise essentially like Hawaiian specimens. A comparison of many specimens will be necessary to show the value of this character.

\section{GLOSSOGOBIUS BRUNNEUS (Schlegel).}

One specimen from Kotosho, apparently exactly like others from Nagasaki; the characteristic cross-lines of dark spots at the nape present.

One very large specimen from Keerun.

The types of Glossogobius Gill, from Hongkong, referred to Gobius platycephalus, must have belonged to this species, having the peculiar notched tongue. 
175. CTENOGOBIUS PLATYCEPHALUS (Richardson).

Five specimens from Kotosho; one from Taihoku; one larger one, No. 348, from Formosa, F. I.

This species much resembles Ctenogobius giuris, but the scales before the dorsal are much larger. It is allied to Glossogobins brunneus, but differs in the characters called generic in Glossogobius, having the tongue not emarginate, and the isthmus broad. The name Glossogobius refers to the emarginate tongue.

We identify our specimens with Richardson's description of Gobius platycephalus with some doubt, as the original account is very incomplete. So far as it goes, however, it agrees with our specimens. Richardson's type came from Macao

\section{Family BLENNIID A.}

I76. SALARIAS NAMIYEI ${ }^{1}$ Jordan and Evermann, new species.

Head 4.5; depth 4.5 ; eye 2.75 ; D. XXXII; A. XXIII; P. 13; V. 2. Body short and compressed; head short and very blunt, the profile from upper lip to top of eye vertical; mouth rather large, low,

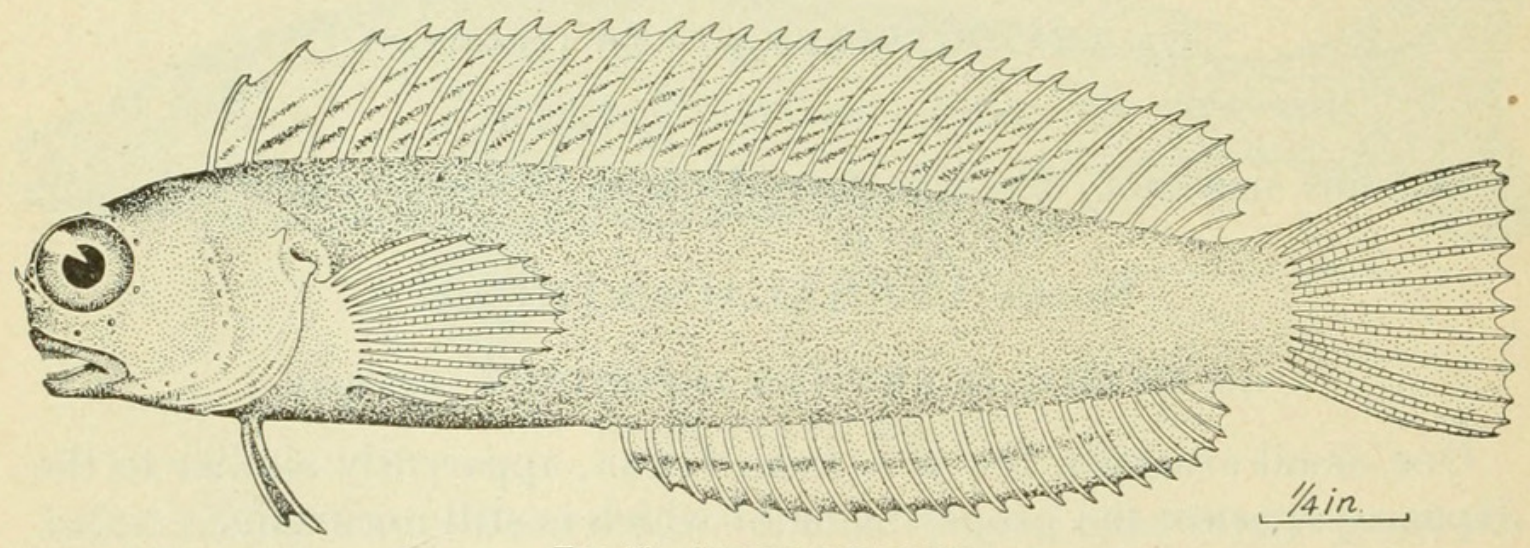

Fig. 25.-SALARIAS NAMTYEI.

nearly horizontal, the lower jaw somewhat the shorter; teeth in a very fine comb-like band on each jaw; eye large, high up, entering the profile; caudal peduncle deep and very thin. Body entirely naked. Dorsal fin very long, beginning on nape, composed entirely of soft flexible spines; anal similar, but beginning under about the thirteenth dorsal spine, the two fins coterminous; caudal truncate; pectoral broad and rounded; ventral of two slender rays and a concealed spine; a pair of short tentacles in front of eye.

${ }^{1}$ Named for Motokiche Namiye, curator in the Museum of the University of Tokyo, author of the earliest systematic account by a native author of the vertebrate animals of Japan. It is entitled Classified Catalogue of the Specimens of Vertebrates in the Collections of the Kiyoiku Hakubutsu Kwan (Educational Museum), Tokyo, 1881 . 
Color in alcohol, purplish red, paler posteriorly; dorsal fin with narrow oblique darker markings; anal darker along the margin, and with a similar median band.

No canines; no tentacles; dorsal not notched, not connected with the caudal; no sharp color markings.

Type.-No. 278, specimen 2.5 inches long from Hokoto, or Pescadores Islands; returned to the Imperial University of Tokyo.

\section{Family CEPOLIDE.}

\section{I77. ACANTHOCEPOLA MESOPRION Bleeker.}

No. 5063, a specimen 13 inches long from Giran.

Head 12; depth 13; eye 2.75; snout 5.5; interorbital 4.5; maxillary 2; mandible 1.8; D. 104; A. 105; pectoral 1.75; ventral 2; scales about 300 .

Body very long, slender, very greatly compressed, tapering gradually from the head, where it is deepest, to the very slender tail, the

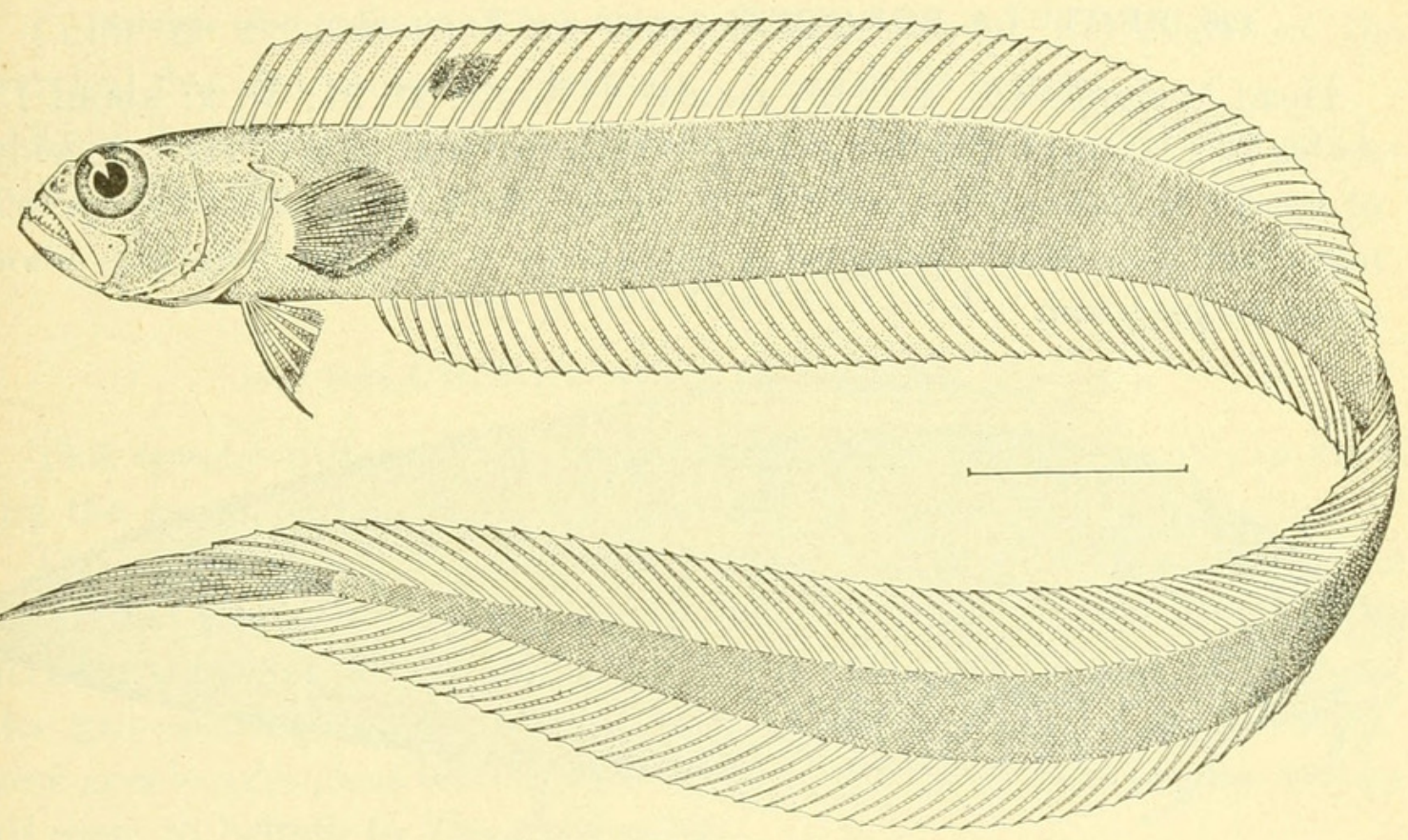

FIG. 26. - ACANTHOCEPOLA MESOPRION.

shape resembling that of the scabbard-fish (Trichiurus lepturus); eye very large, high up, entering the dorsal profile; snout very short; mouth very large, nearly vertical; maxillary broad at tip, reaching past pupil; teeth in a single wide-set row in each jaw, long, recurved, and canine-like; opercle and preopercle very deep, the latter with about 6 short sharp teeth at the angle; scales very small and smooth, covering sides of head and entire body; top of head, maxillary, and lower jaw naked; no lateral line. Dorsal and anal fins very long, each of about 105 soft rays; the dorsal beginning at nape, the third ray over opercular opening, the rays all of about equal length, about 1.75 in head; anal beginning under last third of pectoral, continuous with the caudal, as is the dorsal, the rays quite uniform in length, the longest 
about 1.75 in head; caudal with about 9 rays, the middle ones very long, nearly twice length of head; pectoral short and broad, ventral I, 4 , short, the spine long and slender, 3 in head; vent under nearly middle of pectoral.

Color in alcohol, dirty silvery, the head and body without markings; fins all plain except a large black blotch on membrane between the eighth and eleventh dorsal rays; other fins unmarked.

Dorsal with a large black spot in front; anal with a brown margin; scales extremely small; preopercle with 7 or 8 spinous teeth.

This species is certainly different from the Japanese Acanthocepolg limsenstemi, having minute scales, doubtless over 300 in the lateral line, and a more elongate body. It may be identical with the scantily described Cepola limbata or Cepola marginata of Cuvier and Valenciennes.

\section{Family BROTULIDA.}

178. BROTULA FORMOS $Æ$ Jordan and Evermann, new species.

Head 5; depth 4.5; D. 115 ; caudal 8; A. 83; P. 24; V. 2; about 158 scales in a lateral series between gill-opening and base of caudal; width of head 2 in its length; snout 4.5 in head; eve 4.7 ; interorbital space 6 ; maxillary 2 in head; pectoral a little over 2 in head; ventrals about equal to pectoral.

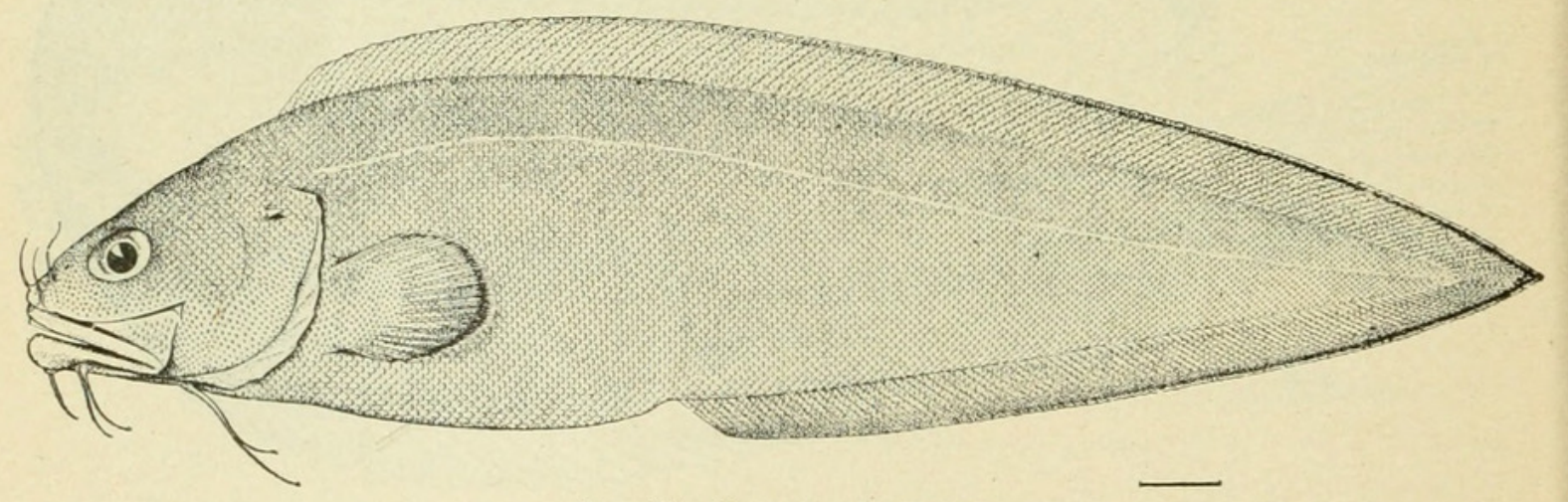

Fig. 27,-Brotula Formose.

Body elongate, compressed, and the tail tapering to a point; head oblong, compressed; snout blunt, rounded, and rather short; eye rather small, anterior and superror; mouth large, the maxillary reaching far behind the eve, and the distal expanded extremity of maxillary about equal to the diameter of the eye; 6 superior barbels, as 2 nasals and 4 labials, and 6 inferior barbels, 3 on each ramus; lips thick and tough; teeth in jaws, on vomer and palatines, in broad, villose bands; nostrils in 2 small tubes, separated by a little space, and upon the sides of the snout; 2 very short rudimentary barbels between each pair of upper labial barbels; interorbital space about $\frac{3}{4}$ the eye, and convex; maxillary fitting under suborbital flap for nearly its whole distance; opercles with a spine above; tongue pointed, smooth, and free in front; 
gill-opening large, the branchiostegal membrane narrowly free over the isthmus; gillrakers $4+18,3$ of which are developed on the upper part of the ceratobranchial, all the others very short, rounded, and finely villous; pseudobranchiæ well developed; branchiostegals rather large, 8 in number; intestine short, of several turns; pyloric cæca 3 , short; peritoneum pale or silvery. Scales small, thin, elongate and cycloid, very small upon the vertical fins, and upon the pectoral, the latter completely covered. Origin of the dorsal before that of the pectoral, the fin of uniform height and confluent with the caudal, which is pointed; origin of the anal much nearer the tip of the snout than base of caudal and similar to dorsal; pectorals broad, rounded, and a little less than halfway to origin of anal; ventrals of two filaments, one much longer than the other and ensheathed in a membrane for half the length of the longer; ventrals inserted slightly nearer posterior margin of eye than edge of opercle; lateral line superior and not particularly distinet.

Color in alcohol, more or less uniform brown, the edges of the vertical fins and pectorals blackish. Length 19 inches.

This description from a female from Formosa, No. 359, F. I., returned to the Imperial Fisheries Institute.

\section{Family PLEURONECTIDA.}

\section{I79. PSEUDORHOMBUS OLIGODON (Bleeker).}

This species differs from Paralichthys arsius (=P. russelli) in having the scales on the blind side ctenoid, like those on the left side.

The genus Pseudorhombus (malayanus; musselli) may be recognized as distinct from Paralichthys, being characterized by the presence of an accessory branch to the lateral line running from the upper edge of the gill-opening to the nape. The American species and the Japanese species olivaceus belong to Paralichthys. The East Indian species all seem to belong to Pseudorhombus.

The species of this type, described by Richardson ${ }^{1}$ from drawings made at Canton, are probably unrecognizable from the descriptions.

One specimen, No. 350, Formosa, F. I.

One specimen, No. 42 x, Formosa, F. I. Gillrakers short, $\mathrm{x}+11$, about one-third diameter of eye. A. 57; scales 78. A dark blotchat angle of lateral line, and another behind; body and fins with dark blotches.

180. PLATOPHRYS MYRIASTER (Schlegel).

One specimen from Keerun. A. 69; scales about 115. Surface covered with small blue spots; two dark spots on lateral line.

Two specimens, Nos. $41 \mathrm{x}$ and $47 \mathrm{x}$, from Formosa, F. I. 
Family SOLEID E.

I8I. LIACHIRUS NITIDUS Günther.

A fine specimen, $t$ inches long (No. 287), from Giran, agreeing with Günther's description.

Head 4.5; depth 2.5 ; snout 3.2 ; D. 63 ; A. 48; V. 5 ; scales about 25-92-35, small and hard to count. Body dextral, the color and eyes being on the right side; body oblong elliptical; snout bluntly rounded; mouth rather large, the gape reaching eyes; eyes close together, small; scales very small, smooth, and rather loosely attached; lateral line extending from near upper eye nearly straight to middle of caudal; dorsal and anal fins rather high, about 1.8 in head.

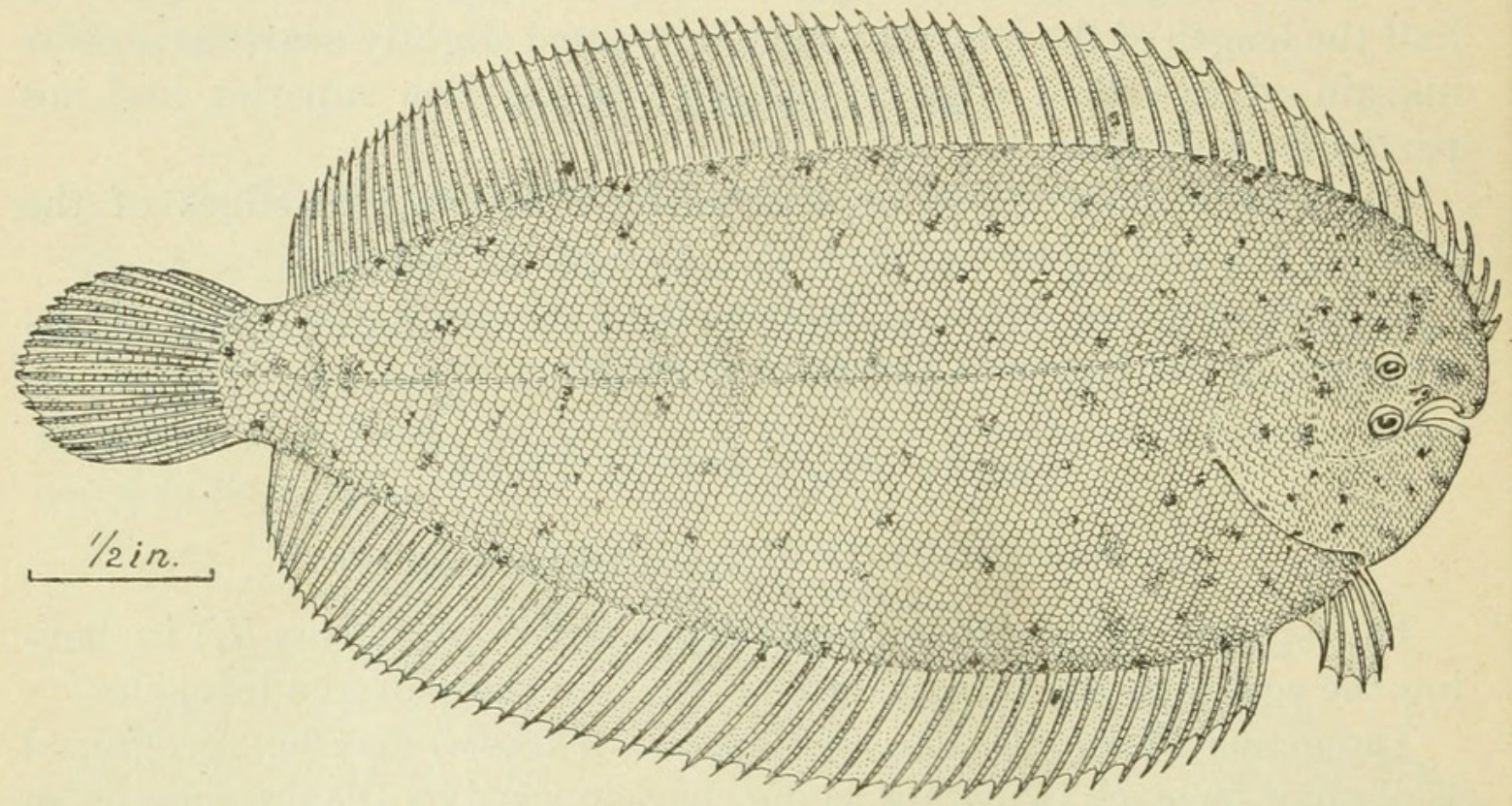

Fig. 28.-LiACHiRI's Nitidus.

Color in alcohol, yellowish-gray, the body and head sparsely cov ered with small, roundish, black spots, a few of these upon dorsal and anal fins; dorsal and anal rays dark edged; caudal with a few dark specks.

I82. SYNAPTURA ORIENTALIS (Schneider).

(Synaplura foliacea Richardson.)

One specimen, No. 369, from Formosa, F. I.

The nostrils in this species are similar to those of Synaptura pan. The genus Euryglossa, based on their supposed peculiarities, is without foundation.

I83. USINOSITA JAPONICA (Schlegel).

One small example from Keerun, similar to examples from Kobe.

184. PARAPLAGUSIA BILINEATA (Bloch).

One specimen, No. 45x, from Formosa, F. I.; one specimen from Keerun. 
185. CYNOGLOSSUS DIPLASIOS Jordan and Evermann, new species.

One large specimen (No. 43) 10.5 inches long, from Formosa, F. I., returned to the Imperial Fisheries Institute. This species is well distinguished by the presence of two complete and well developed lateral lines on either side.

Head 5 in total length; depth 4 ; eye 10 ; snout 2.6 ; D. 112; A. 95; scales about $100,-40$; scales on upper part of head and along base of dorsal fin very strongly ctenoid, elsewhere scarcely or not at all ctenoid; scales on head very much reduced in size; mouth large, fully protected by the upper lip. Body sinistral, that is, the eyes and color

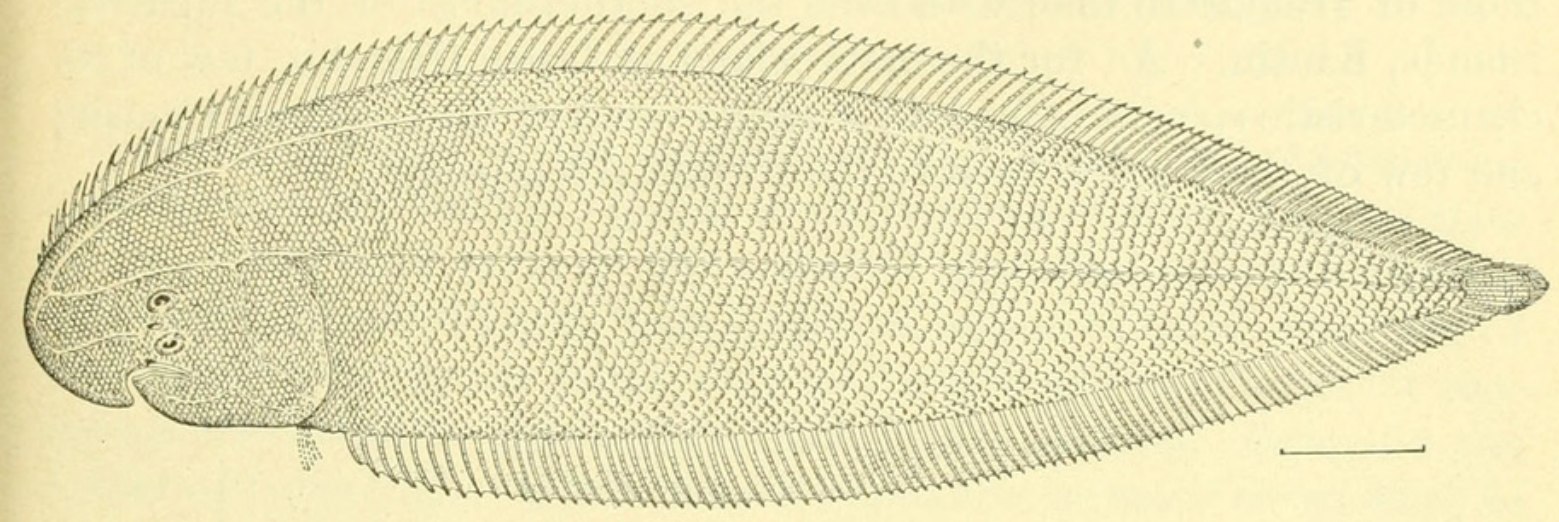

FIG. 29.-CyNOGLOSSUS DIPLASIOS.

on the left side; scales of blind side more smooth than elsewhere; nostril small, tubular, close to eyes; upper eye slightly in advance of lower, equal in size; dorsal beginning on snout in front of eyes; pectorals obsolete.

Color in alcohol, pale dirty-yellowish, the head somewhat darker; no distinct markings anywhere.

\section{ZEBRIAS ZEBRA (Bloch).}

One specimen, No. $44 \mathrm{x}$, from Formosa, F. I., corresponding to Günther's description. D. 80. The figure given by Day ${ }^{1}$ seems to represent some other fish, with the cross-bands not in pairs, and with fewer fin rays.

\section{GENERALIZATIONS.}

It is evident that these collections comprise but a small part of the fish fauna of Formosa, being in fact chiefly made up of the common market fishes. The gobies and blennies, especially abundant in this region, are almost unrepresented, while the equally abundant Callionymidx are wanting altogether. The scant representation of Labridx, Holocentridx and Scorprnidx shows that no effort was made to secure the fishes of the coral reefs, and doubtless many of the commonest species were overlooked or rejected by the collectors. Yet with all

\footnotetext{
${ }^{1}$ Fishes of India, pl. xcrv, fig. 3 .
} 
this, the collections give a fair understanding of the fishes of Formosa. It is evident in the first place that the marine species are essentially those of that part of the coast of China having similar physical conditions. The freshwater fishes are derived from China, but are largely distinct as to species.

Compared with Japan and India, the following statistics may be interesting:

Common to Formosa and Kiusiu

Common to Formosa and Hindostan ............................. 77

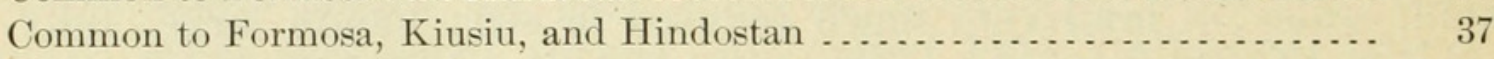

It is evident that the faunal relations of Formosa are closer with those of Hindostan than with even the southernmost of the Japanese islands, Kiusiu. ' As for the main island of Japan (Hondo), few of its characteristic species extend their range south of the Tropic of Cancer; and few of them reach even to the Riukiu Archipelago. 


\section{$2 \mathrm{BHL}$ Biodiversity Heritage Library}

Jordan, David Starr and Evermann, Barton Warren. 1902. "Notes on a collection of fishes from the island of Formosa." Proceedings of the United States National Museum 25(1289), 315-368. https://doi.org/10.5479/si.00963801.25-1289.315.

View This Item Online: https://www.biodiversitylibrary.org/item/32399

DOI: https://doi.org/10.5479/si.00963801.25-1289.315

Permalink: https://www.biodiversitylibrary.org/partpdf/9160

\section{Holding Institution}

Smithsonian Libraries

\section{Sponsored by}

Smithsonian

\section{Copyright \& Reuse}

Copyright Status: NOT_IN_COPYRIGHT

This document was created from content at the Biodiversity Heritage Library, the world's largest open access digital library for biodiversity literature and archives. Visit BHL at https://www.biodiversitylibrary.org. 